Prepared in cooperation with the Bureau of Reclamation

Methow River Studies, Washington-Abundance Estimates from Beaver Creek and the Chewuch River Screw Trap, Methodology Testing in the Whitefish Island Side Channel, and Survival and Detection Estimates from Hatchery Fish Releases, 2013

Open-File Report 2014-1154 



\section{Methow River Studies, Washington-Abundance Estimates from Beaver Creek and the Chewuch River Screw Trap, Methodology Testing in the Whitefish Island Side Channel, and Survival and Detection Estimates from Hatchery Fish Releases, 2013}

By Kyle D. Martens, Teresa M. Fish, Grace A. Watson, and Patrick J. Connolly

Prepared in cooperation with the Bureau of Reclamation

Open-File Report 2014-1154

U.S. Department of the Interior

U.S. Geological Survey 


\section{U.S. Department of the Interior \\ SALLY JEWELL, Secretary}

\section{U.S. Geological Survey \\ Suzette M. Kimball, Acting Director}

U.S. Geological Survey, Reston, Virginia: 2014

For more information on the USGS-the Federal source for science about the Earth,

its natural and living resources, natural hazards, and the environment-visit

http://www.usgs.gov or call 1-888-ASK-USGS

For an overview of USGS information products, including maps, imagery, and publications, visit $h$ ttp://www.usgs.gov/pubprod

To order this and other USGS information products, visit $h$ ttp://store.usgs.gov

Suggested citation:

Martens, K.D., Fish, T.M., Watson, G.A., and Connolly, P.J., 2014, Methow River Studies, Washington-Abundance estimates from Beaver Creek and the Chewuch River screw trap, methodology testing in the Whitefish Island side channel, and survival and detection estimates from hatchery fish releases, 2013: U.S. Geological Survey Open-File Report 2014-1154, 38 p., http://dx.doi.org/10.3133/ofr20141154.

ISSN 2331-1258 (online)

Any use of trade, firm, or product names is for descriptive purposes only and does not imply endorsement by the U.S. Government.

Although this information product, for the most part, is in the public domain, it also may contain copyrighted materials as noted in the text. Permission to reproduce copyrighted items must be secured from the copyright owner. 


\section{Contents}

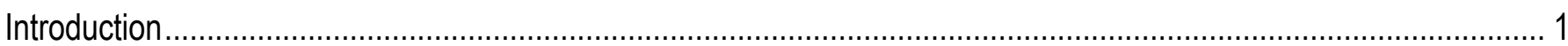

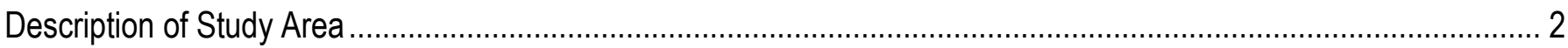

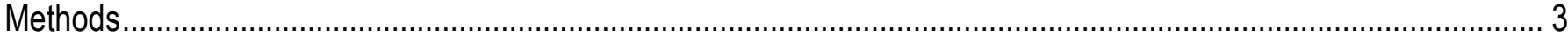

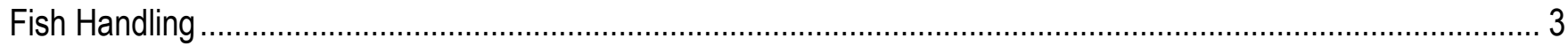

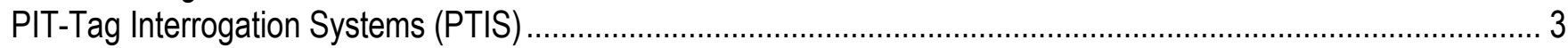

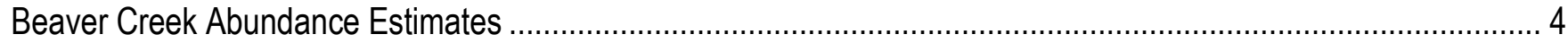

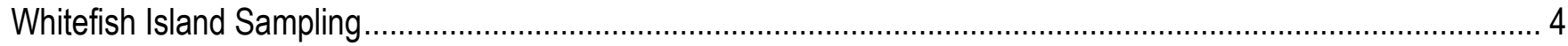

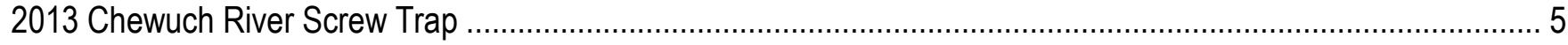

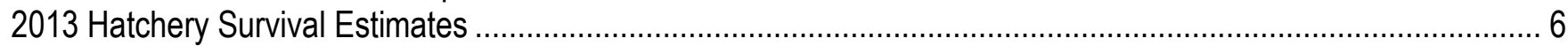

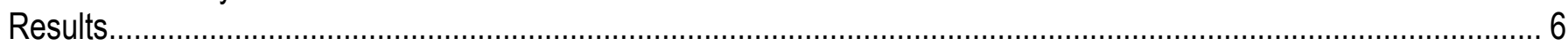

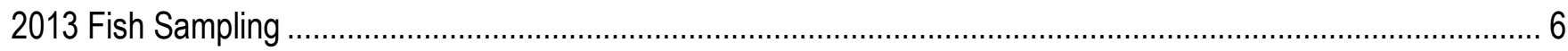

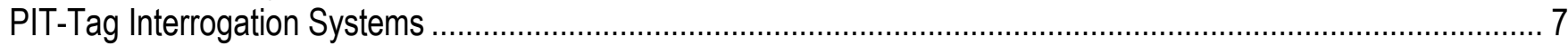

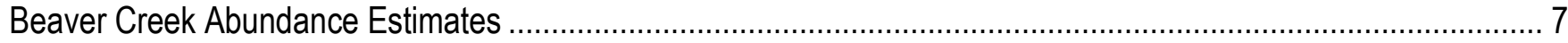

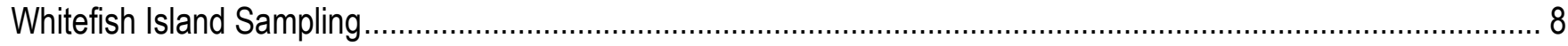

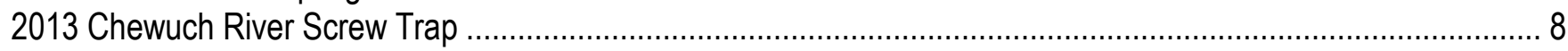

2013 Hatchery Survival Estimates .....................................................................................................

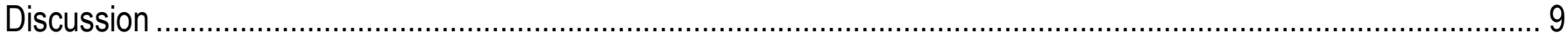

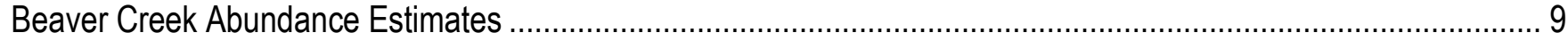

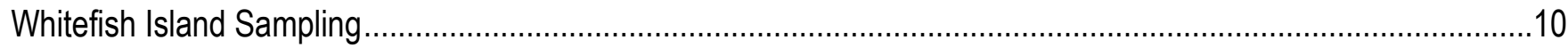

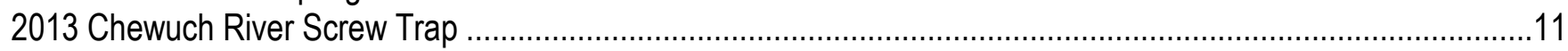

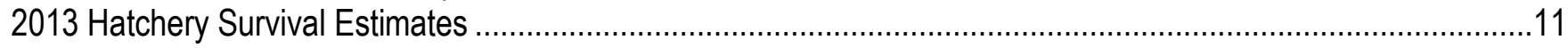

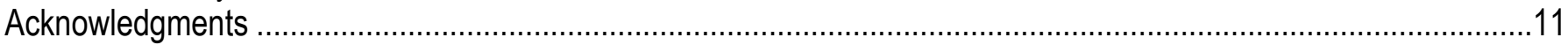

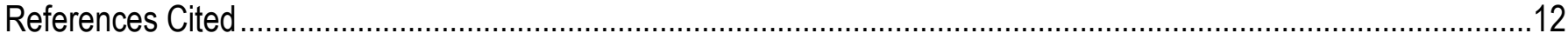

Appendix

\section{Figures}

Figure 1. Map showing key sampling locations in the Methow River watershed, Washington.

Figure 2. Number of juvenile rainbow trout/steelhead (RBT/STH) per meter in Reach 1 (rkm 5) of Beaver Creek, Methow River watershed, Washington, 2004-13.

Figure 3. Number of juvenile rainbow trout/steelhead (RBT/STH) per meter in Reach 2 ( $\mathrm{rkm} 13)$ of Beaver Creek, Methow River watershed, Washington, 2004-13...

Figure 4. Number of juvenile rainbow trout/steelhead (RBT/STH) per meter in Reach 4 (rkm 16) of Beaver Creek, Methow River watershed, Washington, 2004-13...

Figure 5. Number of juvenile Chinook per meter in Reaches 1 and 2 of Beaver Creek, Methow River watershed, Washington, 2004-13

Figure 6. Linear regressions of juvenile Chinook per meter in Reach 1 of Beaver Creek, Methow River watershed, Washington with the average August discharge of Methow River near Pateros flow site from the previous year and number of adult Chinook counted at the Wells Dam adult ladder from the previous year.

Figure 7. Population abundance estimates from multiple-pass, multiple-unit snorkeling compared to three-pass, mark-recapture electrofishing, Whitefish Island side channel, Methow River watershed, Washington ..... 21 Figure 8. Age-0 rainbow trout/steelhead (STH) population abundance estimate in the Whitefish Island side channel, Methow River watershed, Washington, 2008-13...

Figure 9. Age-1 or older rainbow trout/steelhead (STH) population abundance estimate in the Whitefish Island side channel, Methow River watershed, Washington, 2008-13. 
Figure 10. Juvenile Chinook ( $\mathrm{CHN}$ ) population abundance estimate in the Whitefish Island side channel, Methow River watershed, Washington, 2008-13.

Figure 11. Number of pool and riffle habitat units in the Whitefish Island side channel, Methow River

watershed, Washington, before (2008-2012) and after (2013) side channel restoration, following spring high flows

Figure 12. Average depth of pool and riffle habitat units in Whitefish Island side channel, Methow River watershed, Washington, before (2008-12) and after (2013) side channel restoration, following spring high flows ..... 26 Figure 13. Daily number of rainbow trout/steelhead (STH) collected at the Chewuch River screw trap, Methow River watershed, Washington, 2013

Figure 14. Daily number of juvenile Chinook $(\mathrm{CHN})$ collected at the Chewuch River screw trap, Methow River watershed, Washington, 2013

Figure 15. Average probability of detection of hatchery Chinook and steelhead at Methow River PIT tag interrogator in 2013, Methow River watershed, Washington

\section{Tables}

Table 1. Presence and absence of fish species sampled and/or observed by the U.S. Geological Survey in the mainstem Methow, Chewuch, and Twisp Rivers, and Beaver Creek, Methow River watershed, Washington, 2013... 29 Table 2. Streams surveyed or sampled for fish and locations of 4,018 passive integrated transponder (PIT) tags deployed in the Methow River watershed, Washington, 2013

Table 3. Streams surveyed or sampled for fish and locations of nine genetic samples collected in the Methow River watershed, Washington, 2013

Table 4. Passive integrated transponder (PIT) tag interrogation sites and total number of fish detected by species, Methow River watershed, Washington, 2013

Table 5. Results of the top 10 models ranked by $\triangle \mathrm{AIC}$ for $\mathrm{N}$-mixture models completed through multiple-pass multiple-unit snorkeling, Methow River watershed, Washington....

Table 6. Population estimates from Chewuch River screw trap, Methow River watershed, Washington, 2013 .......... 34

\section{Conversion Factors}

Inch/Pound to SI

\begin{tabular}{lcl}
\hline \multicolumn{1}{c}{ Multiply } & \multicolumn{1}{c}{ By } & \multicolumn{1}{c}{ To obtain } \\
\hline inch (in.) & Length & \\
inch (in.) & 2.54 & centimeter $(\mathrm{cm})$ \\
foot (ft) & 25.4 & millimeter $(\mathrm{mm})$ \\
mile (mi) & 0.3048 & meter $(\mathrm{m})$ \\
mile, nautical (nmi) & 1.609 & kilometer $(\mathrm{km})$ \\
yard (yd) & 1.852 & kilometer $(\mathrm{km})$ \\
\hline & 0.9144 & meter $(\mathrm{m})$ \\
\hline cubic foot per second $\left(\mathrm{ft}^{3} / \mathrm{s}\right)$ & Flow rate & \\
\hline
\end{tabular}

Temperature in degrees Celsius $\left({ }^{\circ} \mathrm{C}\right)$ may be converted to degrees Fahrenheit $\left({ }^{\circ} \mathrm{F}\right)$ as follows:

${ }^{\circ} \mathrm{F}=\left(1.8 \mathrm{x}^{\circ} \mathrm{C}\right)+32$

Temperature in degrees Fahrenheit $\left({ }^{\circ} \mathrm{F}\right)$ may be converted to degrees Celsius $\left({ }^{\circ} \mathrm{C}\right)$ as follows:

${ }^{\circ} \mathrm{C}=\left({ }^{\circ} \mathrm{F}-32\right) / 1.8$. 


\title{
Methow River Studies, Washington-Abundance Estimates from Beaver Creek and the Chewuch River Screw Trap, Methodology Testing in the Whitefish Island Side Channel, and Survival and Detection Estimates from Hatchery Fish Releases, 2013
}

\author{
By Kyle D. Martens, Teresa M. Fish, Grace A. Watson, and Patrick J. Connolly
}

\section{Introduction}

Salmon and steelhead populations have been severely depleted in the Columbia River from factors such as the presence of tributary dams, unscreened irrigation diversions, and habitat degradation from logging, mining, grazing, and others (Raymond, 1988). The U.S. Geological Survey (USGS) has been funded by the Bureau of Reclamation (Reclamation) to provide evaluation of on-going Reclamation funded efforts to recover Endangered Species Act (ESA) listed anadromous salmonid populations in the Methow River watershed, a watershed of the Columbia River in the Upper Columbia River Basin, in north-central Washington State (fig. 1). This monitoring and evaluation program was funded to document Reclamation's effort to partially fulfill the 2008 Federal Columbia River Power System Biological Opinion (BiOp) (National Oceanographic and Atmospheric Administration, Fisheries Division 2003). This Biological Opinion includes Reasonable and Prudent Alternatives (RPA) to protect listed salmon and steelhead across their life cycle. Species of concern in the Methow River include Upper Columbia River (UCR) spring Chinook salmon (Oncorhynchus tshawytscha), UCR summer steelhead (O. mykiss), and bull trout (Salvelinus confluentus), which are all listed as threatened or endangered under the ESA. The work done by the USGS since 2004 has encompassed three phases of work. The first phase started in 2004 and continued through 2012. This first phase involved the evaluation of stream colonization and fish production in Beaver Creek following the modification of several water diversions (2000-2006) that were acting as barriers to upstream fish movement. Products to date from this work include: Ruttenburg (2007), Connolly and others (2008), Martens and Connolly (2008), Connolly (2010), Connolly and others (2010), Martens and Connolly (2010), Benjamin and others (2012), Romine and others (2013a), Weigel and others (2013a, 2013b, 2013c), and Martens and others (2014). The second phase, initiated in 2008, focuses on the evaluation of the M2 reach (rkm 6680) of the mainstem Methow River prior to restoration actions planned by Reclamation and Yakama Nation. The M2 study was designed to help understand the inter-relationships between stream habitat and the life history of various fish species to explain potential success or limitations in response to restoration actions. To help document changes derived by restoration, two reference reaches (Upper Methow between rkm 85 and 90, and Chewuch River between rkm 4 and 11) were identified based on relative lack of disturbance, proximity to the restoration reach, and relative unconfined geomorphology. A control reach (Lower Methow between rkm 57 and 64, also referred to as "Silver Reach") was 
identified based on its similar disturbance as the reference reach, proximity to the restoration reach, and relatively unconfined geomorphology. Products to date include Barber and others (2011), Bellmore (2011), Tibbits and others (2012), Bellmore and others (2013), Benjamin and others (2013), Romine and others (2013b), Bellmore and other (2014), Martens and others (2014), and Martens and Connolly (2014). The third phase of work has been to help with the development and to provide data for modeling efforts.

Most of the planned M2 reach restoration is focused on the creation or improvement of offchannel habitat, especially side channels. The pre-restoration portion of this study has been documented by Martens and Connolly (2014). Side channel restoration actions were initiated in 2012 (Whitefish Island side channel, also referred to as SC3; rkm 76) and are planned to continue over the next several years. The Whitefish Island side channel was modified to maintain hydrological connection with the mainstem throughout the year. In addition, several log structures were installed and pools were deepened to create fish habitat. Prior to restoration, this side channel would lose hydrological connection with the mainstem Methow River, leaving one large pool near the bottom of the side channel and several shallow isolated pools that may or may not go dry. In seasonally connected side channels, juvenile salmonid survival in pools less than $100 \mathrm{~cm}$ average depth was lower than in pools greater than $100 \mathrm{~cm}$ average depth (Martens and Connolly, 2014).

In this report, we document our field work and analysis completed in 2013. During 2013, USGS sampling efforts were focused on resampling of three reaches in Beaver Creek, testing methodology in the Whitefish Island side channel, conducting hatchery survival estimates, and operating a screw trap on the Chewuch River (funded by Yakama Nation; fig. 1). The Beaver Creek sampling effort was a revisit of three index sites sampled continuously from 2004 to 2007 to look at the fish response to barrier removal. Methodology testing in Whitefish Island side channel was done to determine the best method for evaluating fish populations after restoration efforts in side channels (previous sampling methods were determined to be ineffective after pools were deepened). Hatchery survival estimates were completed to monitor fish survival in the Methow and Columbia Rivers, while the screw trap was operated to estimate migrating fish populations in the Chewuch River and track passive integrated transponder (PIT)-tagged fish. In addition, we maintained a network of PIT-tag interrogation systems (PTIS), assisted Reclamation with fish removal events associated with stream restoration (two people for 9 days; 14 percent of summer field season), and conducted a stream metabolism study designed to help parameterize and calibrate the stream productivity model (Bellmore and others, 2014) with model validation.

\section{Description of Study Area}

The Methow River is a fifth-order stream in north-central Washington State that drains into the Columbia River at river kilometer (rkm) 843 in the Upper Columbia River Basin. The Methow River has two major tributaries - the Twisp River that enters the Methow River at rkm 66 near the town of Twisp, Washington, and the Chewuch River that enters the Methow River at rkm 80 near the town of Winthrop, Washington. Beaver Creek is a third-order stream that drains westward into the Methow River (rkm 57) just south of Twisp, Washington. Various artificial and natural barriers existed in Beaver Creek prior to restoration actions (initiated in 2000 with most work completed by 2005) aimed at improving anadromous fish passage. 
Anadromous fish travel through nine Columbia River dams between the Methow River and Pacific Ocean. Migrating juvenile PIT-tagged salmonids have the potential to be detected on PIT-tag interrogators located at Rocky Reach, McNary, John Day, and Bonneville Dams and in a PIT-tag trawl in the Columbia River estuary. Adult salmonids have the potential to be detected by PIT-tag interrogators located at Bonneville, John Day, McNary, Priest Rapids, Rocky Reach and Wells Dams. In addition to ESA-listed bull trout, UCR summer steelhead, and UCR spring Chinook, the Methow River has anadromous populations of summer Chinook salmon, coho salmon (O. kisutch), and Pacific lamprey (Entosphenus tridentatus).

\section{Methods}

\section{Fish Handling}

All fish were measured for fork length (FL) to the nearest millimeter, weighed to the nearest 0.1 $\mathrm{g}$, and inspected for external signs of disease. At the Chewuch River screw trap, the crew would determine if juvenile rainbow trout/steelhead were either a smolt (silvery appearance with black color on the edge of caudal fin), transitioning to a smolt (showing both a silvery appearance and parr marks), or a parr (presence of dark parr marks). Most target fish $65 \mathrm{~mm}$ FL or longer were tagged with a 12-mm PIT-tag and fish 55-64 mm FL with an 8-mm PIT-tag. PIT-tagging procedures followed the guidelines outlined by Columbia Basin Fish and Wildlife Authority (1999). All PIT-tag and recapture data were submitted by U.S. Geological Survey (USGS) personnel to the Columbia Basin PIT Tag Information System (PTAGIS) database, which is administered by Pacific States Marine Fisheries Commission (PSMFC).

\section{PIT-Tag Interrogation Systems (PTIS)}

During 2013, six PTIS were operated by the USGS in the Methow River watershed. Three of the PTIS (Chewuch River above Winthrop [CRW], Upper Methow above Winthrop [MRW], and Methow River above Twisp [MRT]) were mainstem sites: the upper watershed sites (CRW, MRW; >80 rkm) had two arrays of antennas, and the MRT site had one array. The antennas at the MRT site did not operate at full capacity during 2013 because a new type of PIT tag transceiver (IS1001-MTS) that required the development of new antenna construction and configuration techniques. One array of six antennas is currently (2014) operating at this site. Of those six antennas, only two were working at full capacity in 2013. After extensive testing with this and other new systems by National Oceanic and Atmospheric Administration (NOAA) Fisheries, it was determined that the reader boards (IS1001) needed to be moved from the main controller to inside each individual antenna. Beaver Creek had one three-array PTIS (BVC) and one single-array PTIS system. There was one two-array PTIS near the mouth of Little Bridge Creek (LBT) in the Twisp River watershed. In December, two-array PTIS were installed at the top and bottom of the Whitefish Island side channel.

In March, three PTIS previously operated by the USGS were transferred to the Washington Department of Fish and Wildlife (WDFW) for operation and maintenance. These included one threearray PTIS on Gold Creek (GLC), one single-array PTIS on Libby Creek (LBC), and one single-array PTIS on Wolf Creek (WFC). In the summer of 2013, nine antennas (three antennas at the MRW PTIS, five antennas at the CRW PTIS, and one antenna at the BVC PTIS) were replaced and several cables that had been damaged during spring runoff were repaired or replaced. A new single-array PTIS is planned for installation in the mainstem Methow River near the town of Carlton in 2014. 


\section{Beaver Creek Abundance Estimates}

In 2013, we conducted population abundance and non-population electrofishing in three reaches (Reach 1, rkm 5; Reach 2, rkm 12; and Reach 4, rkm 16) of Beaver Creek. These electrofishing surveys were completed in the same three reaches that were sampled annually from 2004 through 2007 with intermittent sampling in Reaches 1 and 2 through 2012. Non-population electrofishing occurred in the spring and autumn to collect fish lengths and weights, recapture PIT-tagged fish, and PIT-tag new fish.

Prior to surveys for fish population abundance, we completed habitat unit surveys to delineate habitat unit strata used for assessing fish populations. Field personnel identified habitat unit types (for example, pools, glides, riffles, and side channels), and measured each unit for length in meters (m), average width $(\mathrm{m})$, average depth in centimeters $(\mathrm{cm})$, and maximum depth $(\mathrm{cm})$. For pools, a visual estimate of total cover was made, and subdivided into types of instream cover (large woody debris, small woody debris, substrate, undercut bank, or other) and overhead cover (large woody debris, small woody debris, or other).

We stratified the sampling effort based on habitat unit types (for example, pools, glides, riffles, and side channels) and electroshocked a systematic sample of units within each habitat type. In cases where a habitat unit was unable to be sampled, the next unit of the same strata was sampled. Habitat units selected for electrofishing were blocked off with nets to ensure there was no immigration or emigration of fish. A backpack electrofisher was used to conduct two or more passes (a maximum of six passes) using the removal-depletion methodology (White and others, 1982), as described in Martens and Connolly (2014). The field guides by Connolly (1996) were used to determine the number of passes necessary to achieve the desired level of precision in the population abundance estimate (Coefficient of Variation $[\mathrm{CV}]<25$ percent for young-of-year salmonids and $\mathrm{CV}<12.5$ percent for age- 1 or older salmonids) of each sampling unit for each salmonid species (bull trout, brook trout [Salvelinus fontinalis], Chinook salmon, cutthroat trout [O. clarkii], and rainbow trout/steelhead) and age group (young-of-year and age-1 or older). Fish were visually separated into age- 0 and age- 1 in the field. When the separation point was not obvious in the field, we used an $80 \mathrm{~mm}$ FL as a separation point between age- 0 and age- 1 or older fish. If passes 2 and 3 did not meet the desired level of precision, fish counts from passes 1 and 2 were combined and compared with passes 3 and 4, using the 2-pass field guide by Connolly (1996) with the next lower CV (for example, in place of the 25 percent column, the 12.5 percent column would be used) to determine the need for a fifth pass. On the rare occasion when fish capture counts continued to fail these criteria, we would complete a sixth and final pass. These methods were selected to minimize the number of units sampled and the number of passes per unit. This approach lessened the chance that individual fish would be exposed to the effects of electrofishing while it ensured a high degree of precision in the estimates.

\section{Whitefish Island Sampling}

Deep pools created during restoration of the Whitefish Island side channel rendered previous methods for estimating population abundance inadequate due to fish avoidance from electrofishing. As a result, 2013 was used as a methodology testing year to see if we could generate population abundance estimates in individual habitat units or over the entire side channel, or both. The first method tested was a three-occasion mark-recapture effort using two capture techniques (electrofishing and minnow trap). The second method was a multiple-pass, multiple-unit snorkel effort.

For the mark-recapture estimate, a combination of electrofishing and minnow trapping was used. First, the electrofishing method used for most of the side channel was a single forward pass with block nets above and below the section. One post-treatment pool was unique for its length $(137 \mathrm{~m})$, depth $(3.0$ $\mathrm{m}$ ), and structure (large crib constructed of large wood), so it was independently sampled (to estimate 
populations at the habitat unit level), while the rest of the side channel was electroshocked as if one unit. Once electrofishing was completed and the fish were identified, measured, and tagged, we placed 30 baited minnow traps in pools of the side channel and left them to soak overnight. Traps were baited with a combination of salmon eggs, canned salmon, and Berkley PowerBait $\AA$. In the morning, trapped fish were identified, measured, and tagged and released. We then waited an hour after tagging before starting the next electrofishing effort. Electrofishing and trapping were repeated for 3 consecutive days with the traps removed on the fourth day. Data from the traps and electrofishing were combined into markrecapture events, and analyzed in R (R Core Team, 2014) using the Schnabel estimator for repeated mark-recapture data (Krebs, 1989).

For multiple-pass, multiple-unit snorkel estimates, a habitat unit survey was completed similar to the methods used for Beaver Creek population estimates described earlier. Two crew members snorkeled in each habitat unit in an upstream direction. Fish were separated by species and age-class (age- 0 and age- 1 or older). This effort was repeated 4 times over 3 days. We assumed that there was no immigration, emigration, or mortality over the 3-day survey. Data were analyzed in R (R core Team, 2014) using an N-mixture model (Royle, 2004, and Kery and others, 2005). Individual models were built based on habitat covariates (habitat unit type, area, and average depth) using three distributions (Poisson, Negative Binomial, and Zero Inflation Poisson). An overdispersion parameter, $\hat{c}$, was calculated for the three distributions with the full model to determine if the snorkel data were overdispersed (that is, the snorkel data variation exceeded the variation of the theoretically determined mixture model; Burham and Anderson, 2002). If a model type was greatly overdispersed ( $\hat{c}>4)$, it was removed from consideration. Models of population abundance were ranked using Akaike's Information Criterion (AIC), whereby smaller AIC values represented more realistic models (Burnham and Anderson, 2002). $\triangle \mathrm{AIC}$ models were selected for consideration depending on where they fell on Burnham and Anderson's (2002) three-level scale (0-2, substantial support; 4-7, considerable support; and $>10$, essentially no support). Models with substantial support were considered for use to estimate abundance. Abundance estimates for multiple-pass, multiple-unit snorkel and mark-recapture were graphed to compare differences between the two methods (fig. 7).

\section{Chewuch River Screw Trap}

In 2013, additional funding was provided from Yakama Nation to continue and increase sampling at the Chewuch River screw trap. This additional funding allowed us to conduct population estimates of migrating fish in addition to PIT-tagging fish traveling through the M2 reach. A 5-foot (ft) rotary screw trap was used in the Chewuch River near its confluence with the Methow River. This screw trap was deployed on March 12 and fished through November 20 when ice developed in the river and on the trap, requiring the removal of the trap for fish health and crew safety. The trap was fished every day with the exception of 46 days beginning on May 4 due to high water (discharge greater than 1,000 $\left[\mathrm{ft}^{3} / \mathrm{s}\right]$ ), and for 18 days beginning on September 30 as a result of a federally mandated government shutdown.

The trap was checked at least daily and as often as every 4 hours when required by high river discharges, increased debris loads, or scheduled hatchery fish releases. To determine capture efficiency for the trap, we periodically released PIT-tagged steelhead and Chinook salmon 1.2-km upstream of the trap, hereafter referred to as "efficiency release." PIT-tagged fish were held in a mesh pen in a protected eddy near the trap and released after no more than 2 days (48 hours). Efficiency releases were made when 30 or more fish were collected within a 48-hour holding period. 
Abundance estimates were made for migrating age-0 rainbow trout/steelhead, steelhead smolt, age-1 or older rainbow trout/steelhead, sub-yearling Chinook, and Chinook smolt using actual or estimated daily catch. To estimate missed daily catches, we took the average fish abundance of the 2 days before and the 2 days after the missing period. Following the methods of WDFW (Snow and others, 2012), we calculated abundance estimates based on the number of fish collected, Chewuch River discharge, and trap efficiency. Daily trap efficiency estimates were calculated based on a regression created from efficiency releases and Chewuch River discharge. These efficiency estimates were used to expand fish counts by species and age class into daily abundance estimates. These daily estimates were then combined into total abundance estimates. Formulas for calculating these estimates can be found in Snow and others (2012). Chewuch River discharges were taken from a USGS monitoring site (\#12448000) near Winthrop, Washington. Efficiency releases from 2009 to 2013 were combined to determine trap efficiency, as they produced a lower P-value compared to efficiency estimates in 2013 only.

\section{Hatchery Survival Estimates}

We queried and downloaded tagging and interrogation data, using the PTAGIS database (maintained by Pacific States Marine Fisheries Commission, Portland, Oregon), for 2013 PIT-tagged hatchery Chinook and 2013 PIT-tagged hatchery steelhead released in the Methow River watershed. In 2013, hatchery steelhead were released at three locations - two locations in the mainstem Methow River and one location in the Twisp River. Hatchery spring Chinook were released at five locations- three locations in the mainstem Methow River and one location each in the Twisp and Chewuch Rivers. The data were formatted via the program PitPro (University of Washington, Seattle, Washington). Once formatted, the data were analyzed using the "Live Recaptures" (Cormack-Jolly-Serber; Cooch and White, 2012) feature in the program MARK (Colorado State University, Fort Collins, Colorado) to gain estimates of survival over distance and detection probability. All models were simulated with the logit link, which constrains the parameters between 0 and 1.

\section{Results}

\section{Fish Sampling}

Eight fish species, not including at least one species of sculpin, were observed in the Methow River watershed in 2013 (table 1). Most of these species were in the mainstem Methow or Chewuch Rivers. A total of 4,018 fish were PIT-tagged in the Methow River watershed in 2013-1,793 juvenile Chinook; 1,506 juvenile rainbow trout/steelhead; and 82 juvenile coho. The remaining tags (637 tags or about 16 percent) were implanted in cutthroat trout, bull trout, mountain whitefish (Prosopium williamsoni), longnose dace (Rhinichthys cataractae), and bridgelip suckers (Catostomus columbianus) (table 2). Most of the fish tagged in 2013 were collected from the Chewuch River screw trap. At five mainstem sites within the Upper Methow, Lower Methow, and M2 reaches, electrofishing was used to distribute 225 PIT-tags into target fish species, primarily juvenile rainbow trout/steelhead, and Chinook and coho salmon. An additional 48 PIT-tags were distributed in the Elbow Coulee side channel in the Twisp River while assisting Reclamation's habitat group. Nine fin clips, also referred to as genetic samples, were taken for genetic analysis in 2013. Seven of these genetic samples were taken from bull trout (two from the Whitefish Island side channel and five from the Chewuch River rotary screw trap) and two were taken from coho (one from Whitefish Island side channel and one from Beaver Creek; table 3). 


\section{PIT-Tag Interrogation Systems}

In 2013, 1,015 PIT-tagged fish were detected at the Chewuch River above Winthrop (CRW) PTIS (table 4). Most of the fish detected (608, about 57 percent) at the CRW PTIS were juvenile Chinook. In addition, the CRW detected 84 adult steelhead (63 tagged as adults in Columbia River, 20 tagged as juveniles in the Methow River, and 1 tagged in the Yankee Fork of the Salmon River as a juvenile) and 85 adult spring Chinook ( 75 tagged as adults in the Columbia River, 9 tagged as juveniles in the Methow River, and 1 tagged as a juvenile in the Entiat River). One of these detections was a returning kelt steelhead that was detected as an adult at the CRW PTIS in 2011 and 2013. Sixteen hatchery steelhead smolts released in the Chewuch River in 2010, and 6 released in 2011 were detected as adults at the CRW PTIS in 2013.

In 2013, 152 PIT-tagged fish were detected at the Methow River above Winthrop (MRW) PTIS, with 62 (about 41 percent) of these being adult Chinook ( 56 tagged as adults in the Columbia River and 6 tagged as juveniles in the Methow River; table 4). Two hatchery steelhead smolts released in 2010, two released in 2011, and one released in 2012 were detected as adults at the MRW site in 2013 and six steelhead were tagged in the Columbia River as adults. Five hatchery spring Chinook smolts released in 2011 and nine released in 2012 were detected as adults at the MRW PTIS in 2013.

In 2013, 132 fish were detected at the Beaver Creek (BVC) PTIS (table 4), of which 112 (about 85 percent) were juvenile rainbow trout or steelhead. Fourteen (about 11 percent) were adult steelhead, 4 of which were tagged as juveniles in Beaver Creek (1 tagged in 2008 and 3 tagged in 2011) and 10 were tagged in the Columbia River as adults ( 8 tagged at Priest Rapids Dam and 2 at Wells Dam). Three adult steelhead and 1 adult Chinook were detected at the Upper Beaver Creek PTIS in 2013.

\section{Beaver Creek Abundance Estimates}

Five fish species, not including at least one species of sculpin, were observed in Beaver Creek in 2013 (table 1), including three juvenile coho and one juvenile Chinook in Reach 1. Most PIT-tagged fish in Beaver Creek were juvenile rainbow trout/steelhead (99 percent), with 277 in Reach 1, 145 in Reach 2, and 59 in Reach 4 (table 2). The estimated number of fish per meter in Reach 1 of Beaver Creek was the second highest number of age-0 rainbow trout/steelhead (1.1019) that has been observed since sampling began in 2004 (fig. 2). The number per meter of age-1 or older rainbow trout/steelhead (0.6894) was similar to the previous year's number despite the high number of age-0 fish (1.6630) in 2012 (fig. 2). In 2013, the estimated number of fish per meter in Reach 2 of Beaver Creek was the second lowest number of age-0 (0.2227) and age- 1 or older rainbow trout/steelhead $(0.5512)$ that has been observed since sampling began in 2004 (fig. 3). There was a large spike in the estimated number of age-0 rainbow trout/steelhead in Reach 4 of Beaver Creek in 2013 (0.9017) relative to that observed during 2004-07 (range 0.0974-0.2912; fig. 4). Juvenile Chinook numbers have been sporadic from 2004 through 2013 in Reaches 1 and 2, with none observed in Reach 4 (fig. 5). The number of juvenile Chinook were higher $\left(R^{2}=0.706, P=0.005\right)$ when the previous year's mean August discharge in the Methow River (near Pateros) was higher, with no juvenile Chinook when discharge was less than 400 $\mathrm{ft}^{3} / \mathrm{s}$ (fig. 6). Because this relationship of juvenile Chinook to Methow River discharge appears to be driven by one data point, we removed the data point and re-analyzed the data and found that the relationship was still significant $\left(R^{2}=0.572, P=<0.001\right)$. There was no relationship $\left(R^{2}=0.019, P=\right.$ 0.720 ) between the number of adult returns from the previous year's Wells Dam counts (fig. 6) and the number of juvenile Chinook in Beaver Creek. 


\section{Whitefish Island Sampling}

Seven fish species, not including at least one species of sculpin, were observed in the Whitefish Island side channel in 2013 (table 1). Two bull trout were collected, PIT-tagged, and fin clipped for genetic testing. A total of 306 fish were PIT tagged, most of which were juvenile rainbow trout/steelhead (190, or about 62 percent), and juvenile Chinook (104, or about 34 percent; table 2).

Multiple-pass, multiple-unit snorkel abundance estimates were determined by evaluating models that included habitat based covariates over three distributions. The negative binomial models (NB) never stabilized, possibly due to low detection probabilities, so they were removed from consideration. High levels ( $>4.0)$ of overdispersion were detected in Poisson models (P) for each species, so we focused on Zero Inflation Poisson models (ZIP), which did not show overdispersion. The top model for age-0 steelhead (detection [area, habitat unit type, and the quadratic for average depth]; abundance [quadratic for area, habitat unit type, and average depth]) had a population of 2,216 (95 percent CI 1,966-2,482) fish. All other models had essentially no support $(\triangle \mathrm{AIC}>10)$ when compared to the top model. We selected the top age-1 or older rainbow trout/steelhead model (detection [area, habitat unit type, and average depth]; abundance [average depth]; population $=274$ ), because it ranked highest and produced realistic population abundance estimates, even though five other models showed substantial support $(\triangle \mathrm{AIC}<2$; table 5$)$. The top model for Chinook (detection [area, habitat unit type, and the quadratic for average depth]; abundance [quadratic for average depth]) had a population of 1,755 (95 percent CI; 1,560-1,968) fish. The second and third models both showed substantial support $(\Delta \mathrm{AIC}<2)$, but population estimates produced unrealistic dispersal of fish across the habitat units and were removed from consideration. All other top 10 models showed some support ( $\triangle \mathrm{AIC}<7$ ). Habitat unit type, area, and average depth proved to be important in determining population abundance for all three of the species or life stages evaluated.

Fish abundance estimates from mark-recapture data produced wide confidence intervals compared to population abundance estimates produced using the multiple-unit, multiple-pass snorkeling method (fig. 7). The mark-recapture estimates were lower than the estimates produced by snorkeling efforts. The first year after restoration, snorkeling estimates of age-0 rainbow trout/steelhead, age-1 or older rainbow trout/steelhead, and juvenile Chinook had over 4, 5, and 8 times more than the mean number of fish, respectively, than the years before restoration (figs. 8-10). The first year after modification of the side channel, the number of pools slightly increased from pre-restoration condition, while the number of riffles more than doubled (fig. 11). The average depth of both pool and riffle habitat units also increased after restoration (fig. 12).

\section{Chewuch River Screw Trap}

A total of 7,699 fish were collected from nine fish species not including at least one species of sculpin including rainbow trout/steelhead, Chinook, bull trout, cutthroat trout, brook trout, mountain whitefish, bridgelip sucker, longnose dace, and Pacific lamprey (ammocoetes; the larval stage of lamprey) in 2013. Eighteen efficiency releases were completed in discharges ranging from 191 to 887

$\mathrm{ft}^{3} / \mathrm{s}$. A total of 123 age- 0 rainbow trout/steelhead were observed at the trap from which we extrapolated to estimate that 1,687 (95 percent CI; 1,185-2,188) passed the trap site (table 6). Age-0 rainbow trout/steelhead were first captured at the end of June and collected through the end of the trapping season in November (fig. 13). Average weekly lengths of age-0 rainbow trout/steelhead started at 25 $\mathrm{mm}$ FL (late June) and reached a maximum of $99 \mathrm{~mm}$ FL in the autumn (table A1). A total of 416 age- 1 or older rainbow trout/steelhead were observed at the trap from which we estimated 18,337 (95 percent CI; 10,322-26,431) fish (table 6). Most age-1 or older rainbow trout/steelhead were captured just prior to spring runoff from March through June, although they were present throughout the season with a 
secondary peak in September (fig. 13). Average weekly lengths of age-1 or older rainbow trout/steelhead generally increased throughout the season ranging from 80 to $210 \mathrm{~mm}$ FL (table A1). A total of 239 steelhead smolts were collected at the trap from which we estimated 15,227 (95 percent CI; 9,636-20,817) fish (table 6). Steelhead smolts were collected from March through June (fig. 13), with average weekly lengths of steelhead smolts ranging from 115 to $166 \mathrm{~mm}$ FL (table A1).

A total of 2,170 sub-yearling Chinook were collected at the trap from which we estimated 44,019 (95 percent CI; 27,856-60,182) fish (table 6). Sub-yearling Chinook were encountered throughout the entire season of trapping with most captured prior to the spring runoff in March through June, with a second smaller pulse in autumn (fig. 14). Average weekly lengths of sub-yearling Chinook started at $34 \mathrm{~mm}$ FL, and increased throughout the season with a peak of $98 \mathrm{~mm}$ FL during the week of August 26th (table A1). A total of 764 Chinook smolts were collected from which we estimated 15,494 (95 percent CI; 10,786-20,201) fish (table 6). Average weekly lengths of Chinook smolts ranged from 84 to $95 \mathrm{~mm}$ FL from March through June (table A1).

\section{Hatchery Survival Estimates}

Survival and detection probability estimates were produced for six hatchery releases of spring Chinook and three releases of steelhead (table A2). In addition, we produced estimates using a combination of all hatchery fish by species with and without the Lower Methow River (LMR) PTIS. Hatchery steelhead released in the Methow River watershed (no LMR) had a probability of survival of 0.575 (95 percent CI, 0.569-0.581) from release to the Columbia River estuary with a probability of detection at 0.308 (95 percent CI, 0.302-0.315). Hatchery spring Chinook released in the Methow River watershed (no LMR) had a probability of survival of 0.565 (95 percent CI, 0.559-0.571) from release to the Columbia River estuary with a probability of detection at 0.288 (95 percent CI, 0.282-0.295). The average probability of detection of the MRT and LMR PTIS was very low $(<0.01)$ for juvenile salmonids during the high discharges normally associated with the spring smolt migration (fig. 15), although the MRT PTIS was only operating with two fully-functioning antennas.

\section{Discussion}

\section{Beaver Creek Abundance Estimates}

Reach 1 of Beaver Creek has not had a detectable increase in age- 0 or age- 1 or older rainbow trout/steelhead after barrier removal from 2003 to 2004. Reach 2 has shown the most variability of all sites. Reach 4 had a large number of age-0 fish in 2013 compared to sampling done in 2004 through 2007. Continued sampling would need to be done to determine if the increase in age- 0 fish in 2013 was a result of barrier removal or a 1-year anomaly. The lack of a larger response after barrier removal may be due to lack of adult steelhead available to colonize Beaver Creek, or dependent on more time for response, or both (Martens and others, 2010; Weigel and others, 2013c). Juvenile Chinook were rarely present in Beaver Creek from 2004 through 2013. There was no relationship between adult Chinook return numbers at Wells Dam from the previous year to the number of fish per meter in Beaver Creek. There was a significant relationship between the previous year's average discharge in August to the number of juvenile fish per meter in Beaver Creek, with no juvenile Chinook in Beaver Creek when the previous year's mainstem average discharge in August was less than $400 \mathrm{ft}^{3} / \mathrm{s}$. 


\section{Whitefish Island Sampling}

Multiple-pass, multiple-unit snorkeling was more accurate at estimating population abundance (based on 95 percent confidence intervals [CI]) than mark-recapture electrofishing. In addition, multiple-pass, multiple-unit snorkeling would allow for estimating populations at the habitat unit level. We could not collect enough recaptured fish in individual pools, some with depths greater than $2 \mathrm{~m}$ after restoration, through electrofishing to produce comparable population abundance estimates. Even though we recommend snorkeling to determine population abundance, electrofishing and PIT-tagging would still be required in individual habitat units to determine fish biomass, movement, and survival (this would be dependent on the number of fish that remain within the side channel and the number of fish tagged). The habitat unit types, area, and average depth were important factors in determining fish population abundance. Additional covariates, such as structure type and the number of pieces of wood, based on specific types of instream modifications should be evaluated in future studies.

In the first year after restoration, fish abundance was higher than pre-restoration levels of the side channel in August. Additional sampling should be done in autumn and spring because these seasons had a low survival rate prior to restoration of the side channel (Martens and Connolly, 2014). Two bull trout were collected in the Whitefish Island side channel, indicating a potential increase of predatory fish use in the side channel after restoration. Before restoration, we found minimal use of predatory fish in this side channel (Martens and Connolly, 2014). The potential increase in predatory fish should be monitored, especially for their effect on juvenile rainbow trout/steelhead and Chinook. The number of habitat units and average depths in the Whitefish Island side channel increased during August, just after spring runoff. The increase in the number of riffles was a result of formerly dry sections of the side channel maintaining water after restoration.

It would be more appropriate to compare these habitat indicators in autumn and spring (during low-flow levels) when differences between pre-restoration conditions would be more pronounced and fish survival was found to be decreased in shallow pools ( $<100 \mathrm{~cm}$; Martens and Connolly, 2014). In addition, we caution that a single event (August sample) fish population increase after restoration may not represent successful restoration because the fate of these fish is still unknown and the entire watershed may have experienced a year with higher salmonid production and not a specific response to restoration. Due to possible annual variability in fish and habitat conditions, we suggest that the complete before-after-control-impact (BACI) design, as originally planned, should be implemented to evaluate possible changes due to restoration of the side channel. This design includes sampling of 10 side channels of variable hydrologic connectivity (Martens and Connolly, 2014; Martens and others, 2014). Smith and others (1993) found that the BACI design is one of the best methods for impact assessment. With fish populations showing considerable variation in natural settings, Smith and others (1993) noted that increasing the number of before and after samples will decrease the amount of change needed to determine a significant difference after restoration. 


\section{Chewuch River Screw Trap}

Juvenile rainbow trout/steelhead and Chinook were trapped in both autumn and spring. Increased trapping intensity during the 2013 field season provided for more consistent trapping operations that resulted in the ability to produce population estimates for migrating fish. These population estimates had broad confidence intervals, especially in steelhead smolts and age- 0 Chinook ( $>87$ percent steelhead smolt of the estimate; $>73$ percentage-0 Chinook of the estimate). Rayton and Arteburn (2008) found that "noisy data" from screw traps often resulted in broad confidence intervals that were difficult to interpret. To improve on population estimates from 2013, we suggest adding more efficiency releases (which could be done by decreasing the minimum number of fish per release from 30 to 15 , if fish numbers for a release were a constraint) within the 48-hour holding period. Additional years of trapping data could allow us to create trap efficiency estimates by species and season resulting in more precise estimates. A debris deflector should be installed to help keep the trap operating during high river discharges, when debris has the potential to stop or clog up the trap.

\section{Hatchery Survival Estimates}

Overall survival of hatchery-released steelhead and Chinook were greater than 50 percent from fish released in the Methow River. These fish have to travel more than $840 \mathrm{~km}$ and through nine Columbia River dams on their way to the Pacific Ocean. Current low numbers of PIT-tagged fish releases and low detection efficiencies of downstream juvenile fish at the MRT and LMR PTIS render Methow River reach-based survival estimates unreliable. We recommend modifying all of the existing antennas and adding a second array of antennas at the MRT PTIS to help improve PIT-tag detection and increasing the number of hatchery PIT-tagged fish.

\section{Acknowledgments}

Lending assistance in the field work were U.S. Geological Survey (USGS) personnel including: Kyle Koger, James Ryan Bellmore, and Brad Liedtke. Field help from Kraig Mott, Taylor Spaulding, Jason Hickman, Casey Heemsah, and John Hagan of the Yakama Nation was much appreciated. Edward Jones of the USGS guided us through the use of the N-mixture models. Charlie Snow and others at the Washington Department of Fish and Wildlife (WDFW) assisted with the screw trap analysis. Access was granted to work on the side channels and tributaries from various landowners including: Vic Stokes, Carolyn Clancy, Jim Habermehl, Blaine Rogers, and Methow Salmon Recovery Foundation (MSRF). The Methow River work was supported from a larger effort funded by the Bureau of Reclamation, which was administered by Michael Newsom. In addition, Jennifer Molesworth of Reclamation helped to support the project from the Twisp field station. The smolt trapping effort was funded by Yakama Nation. Finally, we would like to thank Brian Fisher and James Ryan Bellmore for reviewing this report. 


\section{References Cited}

Barber, J.J., Gerow, K.G., Connolly, P.J., and Singh, S., 2011, Estimating the proportion of hatchery fish that stray or residualize-A Bayesian approach: North American Journal of Fisheries Management, v. 31, p. 934-942.

Bellmore, J.R., 2011, The ecological importance of floodplains in montane river networksImplications for habitat restoration and salmon recovery: Doctoral dissertation, Idaho State University, Pocatello, Idaho.

Bellmore, J.R., Baxter, C.V., Martens, K., and Connolly, P.J., 2013, The floodplain food web mosaicA study of its importance to salmon and steelhead with implications for their recovery: Ecological Applications v. 23, p. 189-207.

Bellmore, J.R., Fremier, A.K., Mejia, F., and Newsom, M., 2014, The response of stream periphyton to Pacific salmon-Using a model to understand the role of environmental context: Freshwater Biology, DOI: $10.1111 /$ fwb.12356.

Benjamin, J.R., Connolly, P.J., Romine, J.G., and Perry, R.W., 2012, Potential effects of changes in temperature and food resources on life history trajectories of juvenile Oncorhynchus mykiss: Transactions of the American Fisheries Society, v. 142, p. 206-220.

Benjamin, J.R., Wetzel, L.A., Martens, K.D., Larsen, K., and Connolly, P.J., 2013, Spatio-temporal variability in movement, age, and growth of mountain whitefish (Prosopium williamsoni) in a river network based upon PIT tagging and otolith chemistry: Canadian Journal of Fisheries and Aquatic Sciences, v. 71, p. 131-140, http://www.nrcresearchpress.com/doi/pdf/10.1139/cjfas-2013-0279.

Burnham, K.P., and Anderson, D.R., 2002, Model selection and multimodel inference-A practical information-theoretic approach (2d ed.): New York, Springer, 488 p.

Columbia Basin Fish and Wildlife Authority, 1999, PIT tag marking procedures manual: Columbia Basin Fish and Wildlife Authority, Portland, Oregon.

Connolly, P.J., 1996, Resident cutthroat trout in the central Coast Range of Oregon-Logging effects, habitat associations, and sampling protocols: Doctoral dissertation, Oregon State University, Corvallis, Oregon.

Connolly, P.J., 2010, Guidelines for calculating and enhancing detection efficiency of PIT tag interrogation systems, chapter 7 of Wolf, K.S., and O’Neal, J.S., eds., Tagging, Telemetry and Marking Measures for Monitoring Fish Populations-A compendium of new and recent science for use in informing technique and decision modalities: Pacific Northwest Aquatic Monitoring Partnership Special Publication, 2010-002, p. 119-125, accessed February 20, 2013, at http://www.pnamp.org/sites/default/files/ttmchap07.pdf .

Connolly, P.J., Jezorek, I.G., Martens, K.D., and Prentice, E.F., 2008, Measuring performance of two stationary interrogation systems for detecting downstream and upstream performance of PIT-tagged salmonids: North American Journal of Fisheries Management, v. 28, p. 402-417.

Connolly, P.J., Martens, K.D., Weigel, D.E., and Tibbits, W.T., 2010, Effectiveness of actions in Beaver Creek, in Ward, M.B., Morgan, J., and Baldwin, C., eds., Upper Columbia Regional Technical Team 2010 analysis workshop synthesis report: Prepared for Upper Columbia Salmon Recovery Board (UCSRT) by the Upper Columbia Regional Technical Team (UCRTT) and Terraqua, Inc., Wenatchee, Washington, p. 54-57, accessed January 6, at http://www.ucsrb.com/Editor/assets/ucrtt\%202010\%20synthesis\%20report.pdf.

Cooch, E., and White, G., 2012, A gentle introduction to the program MARK: Colorado State University, Fort Collins, Colorado.

Kery, M., Royle, J.A., and Schmid, H., 2005, Modeling avian abundance from replicated counts using binomial mixture models: Ecological Applications, v. 15, p. 1,450-1,461. 
Krebs, C.J., 1989, Ecological methodologies: New York, Harper and Row, 654 p.

Martens, K.D., and Connolly, P.J., 2008, Lower Methow tributaries intensive effectiveness monitoring study-Interim report: Prepared for U.S. Bureau of Reclamation by the U.S. Geological Survey and Western Fisheries Research Center, Columbia River Research Laboratory, Cook, Washington, 77 p.

Martens, K.D., and Connolly, P.J., 2010, Effectiveness of a redesigned water diversion using rock vortex weirs to enhance longitudinal connectivity for small salmonids: North American Journal of Fisheries Management, v. 30, p. 1,544-1,552.

Martens, K.D., and Connolly, P.J., 2014, Juvenile anadromous salmonid production in Upper Columbia River side channels with different levels of hydrological connection: Transactions of the American Fisheries Society, v. 143, p. 757-767.

Martens, K.D., Tibbits, W.T., Watson, G.A., Newsom, M.A., and Connolly, P.J., 2014, Methow and Columbia Rivers studies - Summary of data collection, comparison of database structure and habitat protocols, and impact of additional PIT tag interrogation systems to survival estimates, 2008-2012: U.S. Geological Survey Open-File Report 2014-1016, 92 p., http://pubs.usgs.gov/of/2014/1016/pdf/ofr2014-1016.pdf.

National Oceanographic and Atmospheric Administration, Fisheries Division, 2003, Research, monitoring and evaluation plan for the NOAA-Fisheries 2000 Federal Columbia River Power System Biological Opinion: Editors: C. Jordan, J. Geiselman, M. Newsom, and J. Athearn.

Raymond, H.L., 1988, Effects of hydroelectric development and fisheries enhancement on spring and summer Chinook salmon and steelhead in the Columbia River Basin: North American Journal of Fisheries Management, v. 8, p. 1-24.

Rayton, M.D., and Arterburn, J.E., 2008, 2007 Okanogan Basin monitoring and evaluation program rotary screw trap report: Colville Tribes Fish and Wildlife Department, Anadromous Fish Division, Omak, Washington, $27 \mathrm{p}$.

R Core Team, 2014, R: A language and environment for statistical computing: R Foundation for statistical computing, Vienna, Austria, http://www.R-project.org.

Romine, J.G., Benjamin, J.R., Perry, R.W., Casal, L., Connolly, P.J., and Sauter, S.T., 2013a, Theoretical life history responses of juvenile Oncorhynchus mykiss to changes in food availability using a dynamic state-dependent approach: U.S. Geological Survey Open-File Report 2013-1154, 20 p, http://pubs.usgs.gov/of/2013/1154/.

Romine, J.G., Perry, R.W., and Connolly, P.J., 2013b, Using broad landscape level features to predict redd densities of steelhead trout (Oncorhynchus mykiss) and Chinook Salmon (Oncorhynchus tshawytscha) in the Methow River watershed, Washington: U.S. Geological Survey Open-File Report 2013-1232, 22 p., http://pubs.usgs.gov/of/2013/1232/.

Royle, J.A., 2004, N-Mixture models for estimating population size from spatially replicated counts: Biometrics, v. 60, p. 108-105.

Ruttenberg, D., 2007, An evaluation of fish passage at rock vortex weirs: Master's thesis, University of Idaho, Moscow, Idaho, $262 \mathrm{p}$.

Smith, E.P., Orvos, D.R., and Cairns, J., Jr., 1993, Impact assessment using the before-after-controlimpact (BACI) model-Concerns and comments: Canadian Journal of Fisheries and Aquatic Sciences, v. 50, p. 627-637.

Snow, C., Frady, C., Repp, A., Murdoch, A., Small, M.P., and Bell, S., 2012, Monitoring and evaluation of Wells Hatchery programs - 2011 annual report: Washington Department of Fish and Wildlife, Twisp, Washington, accessed February 2, 2014, at http://docs.streamnetlibrary.org/StreamNet_References/WAsn17094.pdf. 
Tibbits, W.T., Martens, K.D., and Connolly, P.J., 2012, Monitoring of stream restoration habitat on the mainstem of the Methow River, Washington, during the pre-treatment phase (October 2008-May 2012) with a progress report for activities from March 2011 to November 2011: U.S. Geological Survey Open-File Report 2012-1108, 16 p., http://pubs.usgs.gov/of/2012/1108/.

Weigel, D., Connolly, P.J., and Powell, M., 2013a, Fluvial rainbow trout contribute to the colonization of steelhead (Oncorhynchus mykiss) in a small stream: Environmental Biology of Fishes, 11 p., DOI 10.1007/s10641-013-0204-9, http://link.springer.com/article/10.1007/s10641-013-02049/fulltext.html.

Weigel, D., Connolly, P.J., and Powell, M., 2013b, The impact of small irrigation diversion dams on the contemporary migration rates of steelhead and redband trout (Oncorhynchus mykiss): Conservation Genetics, v. 14, p. 1,255-1,267.

Weigel, D., Connolly, P.J., Martens, K.D., and Powell, M., 2013c, Colonization of steelhead (Oncorhynchus mykiss) in a natal stream after barrier removal: Transactions of the American Fisheries Society, v. 142, p. 920-930.

White, G.C., Anderson, D.R., Burnham, K.P., and Otis, D.L., 1982, Capture-recapture and removal methods for sampling closed populations. Los Alamos National Laboratory, LA-8787-NERP, UC-11, Los Alamos, New Mexico. 


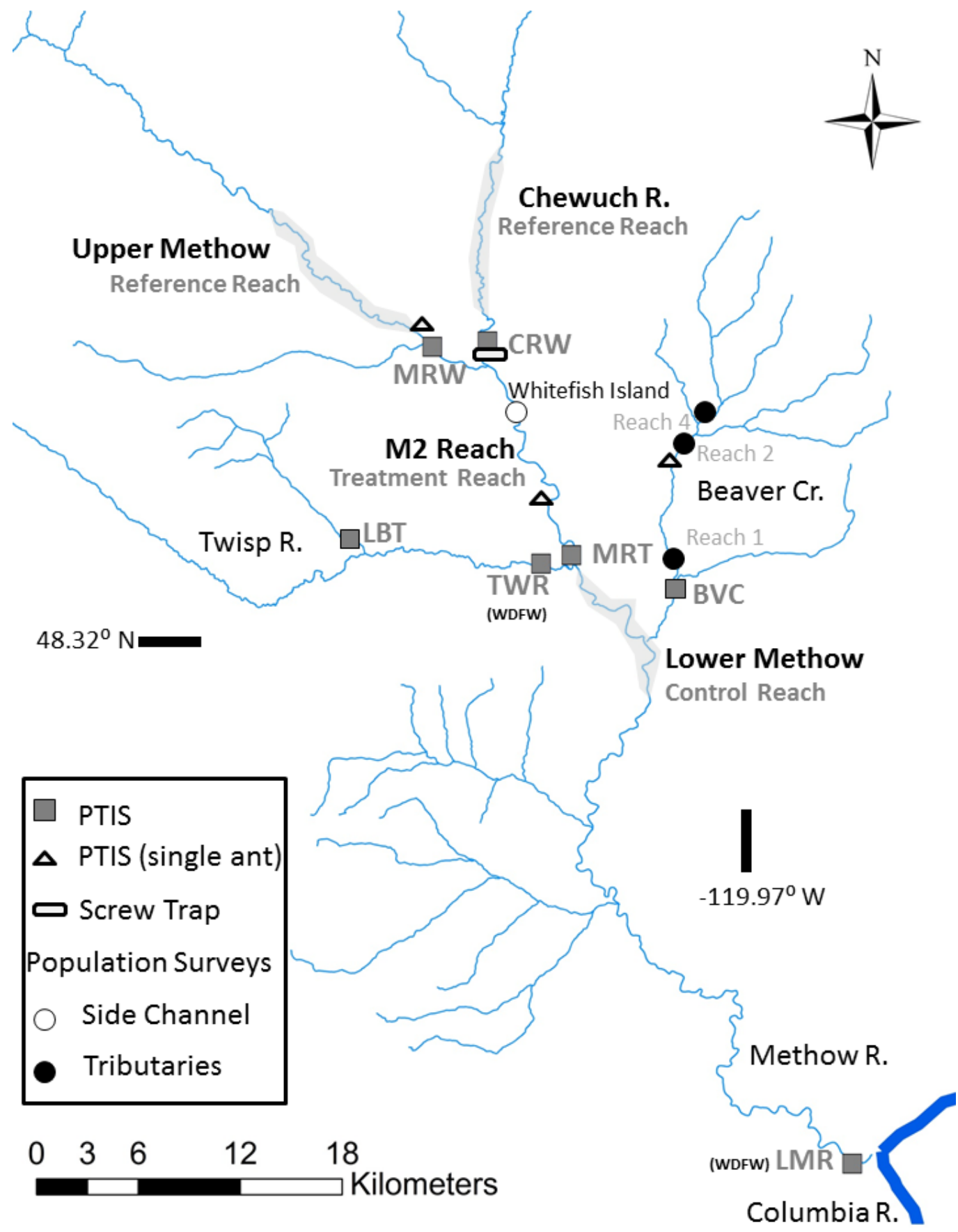

Figure 1. Map showing key sampling locations in the Methow River watershed, Washington. BVC, Beaver Creek; CRW, Chewuch River above Winthrop; LBT, Little Bridge Creek; LMR, Lower Methow River; MRT, Methow River above Twisp; MRW, Methow River above Winthrop; TWR, Twisp River; PTIS, PIT tag interrogation system. 


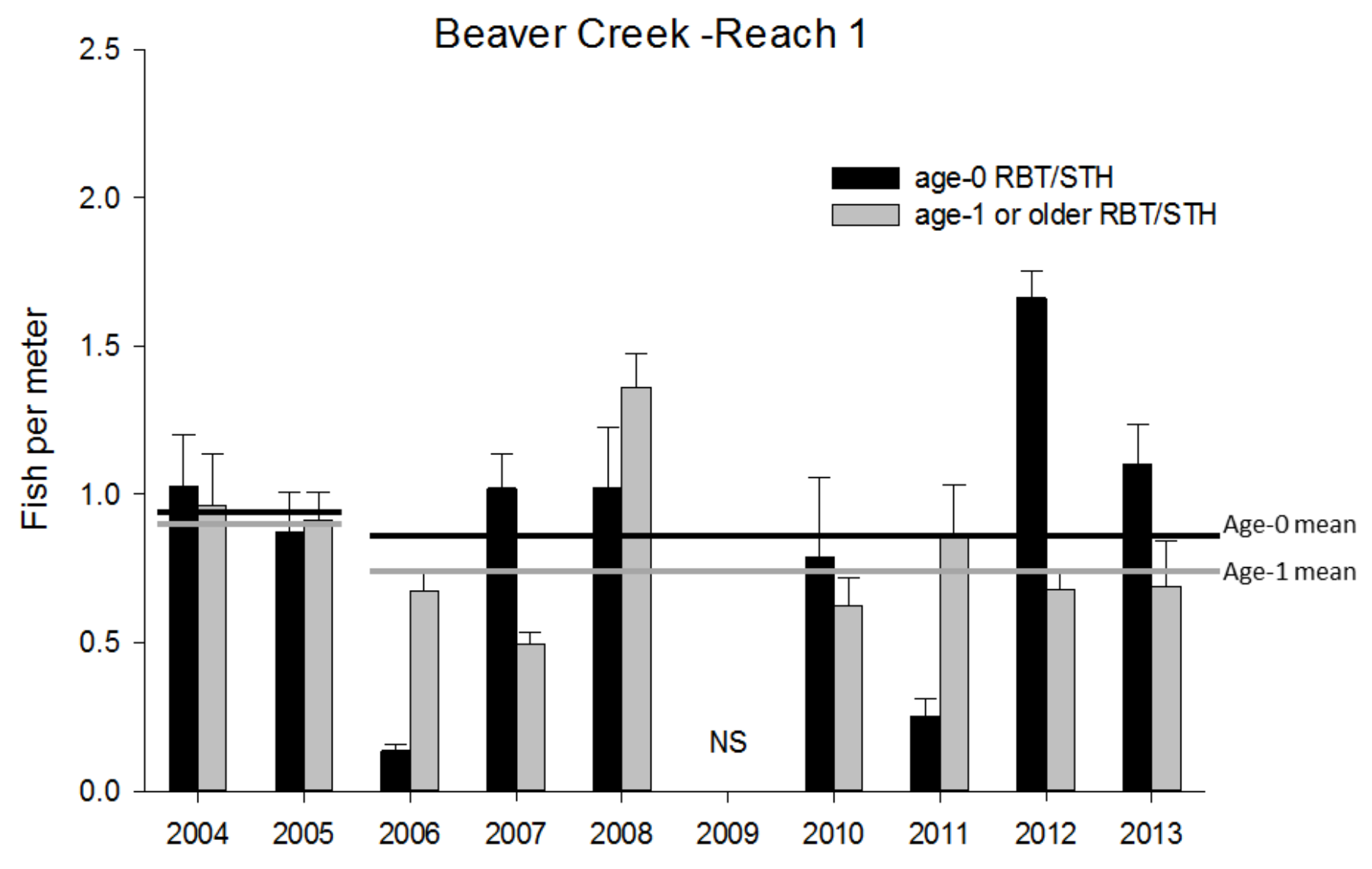

Figure 2. Number of juvenile rainbow trout/steelhead (RBT/STH) per meter in Reach 1 ( $\mathrm{rkm} 5$ ) of Beaver Creek, Methow River watershed, Washington, 2004-13. NS, not sampled. 


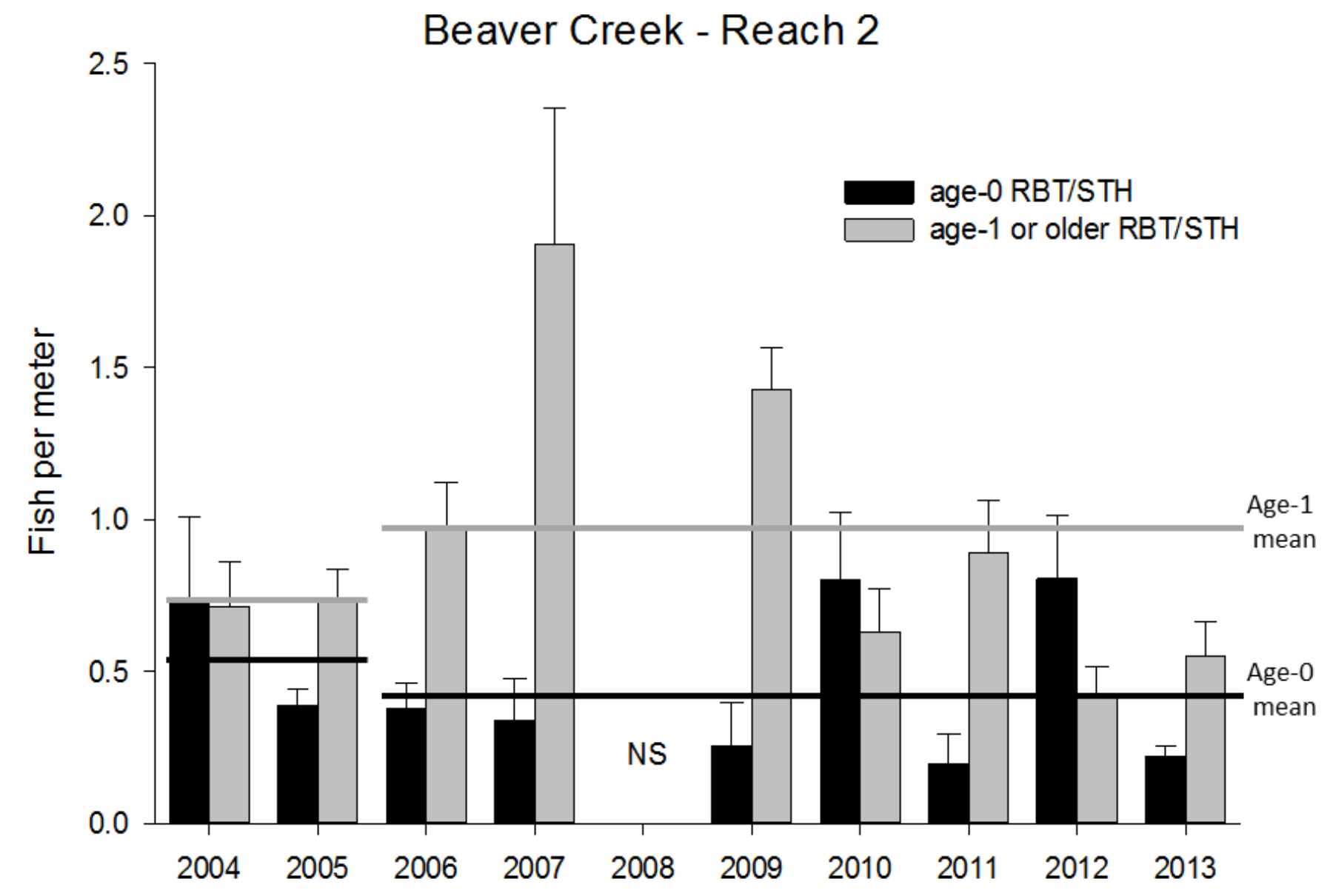

Figure 3. Number of juvenile rainbow trout/steelhead (RBT/STH) per meter in Reach 2 (rkm 13) of Beaver Creek, Methow River watershed, Washington, 2004-13. NS, not sampled. 


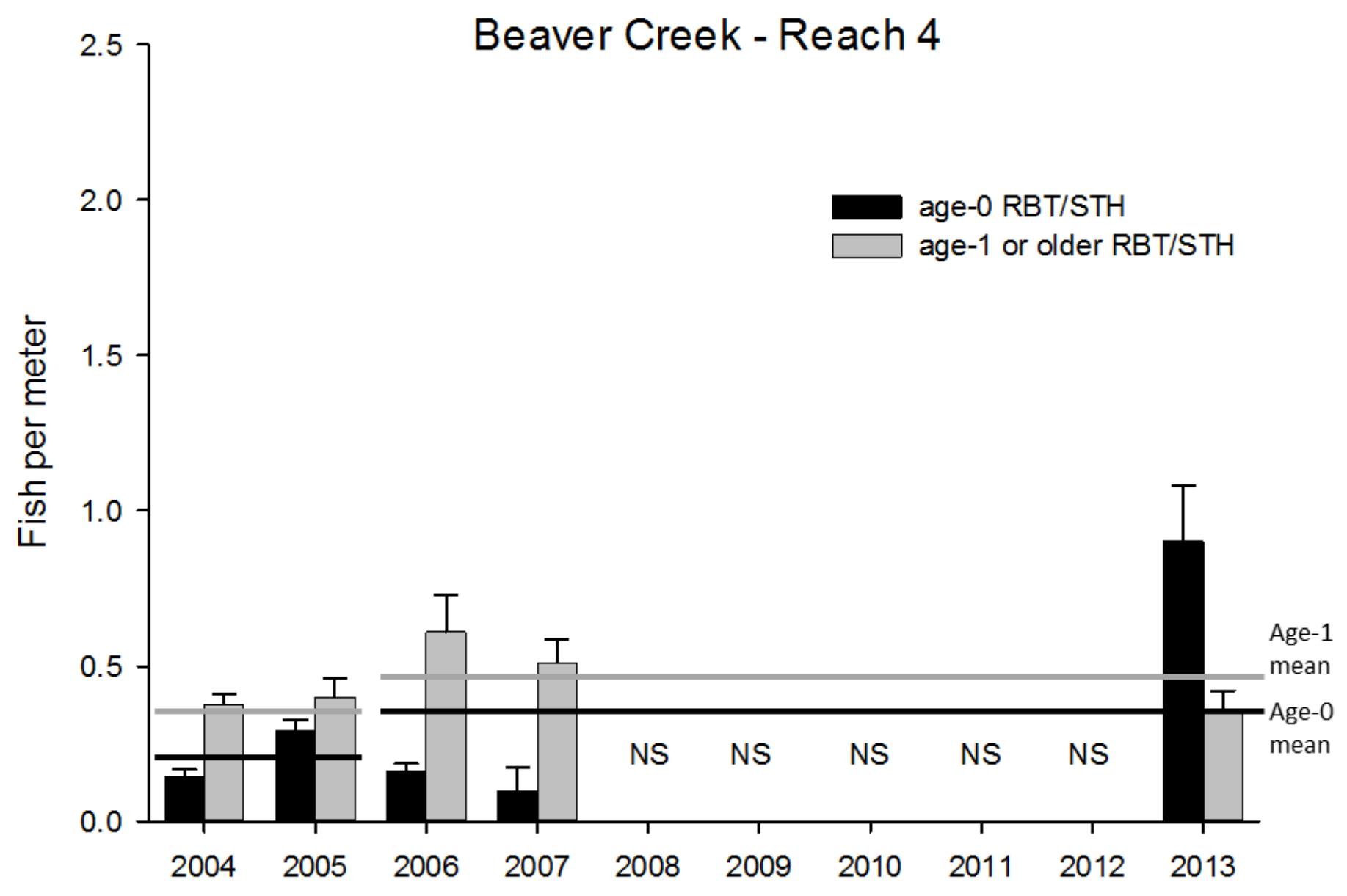

Figure 4. Number of juvenile rainbow trout/steelhead (RBT/STH) per meter in Reach 4 (rkm 16) of Beaver Creek, Methow River watershed, Washington, 2004-13. NS, not sampled. 


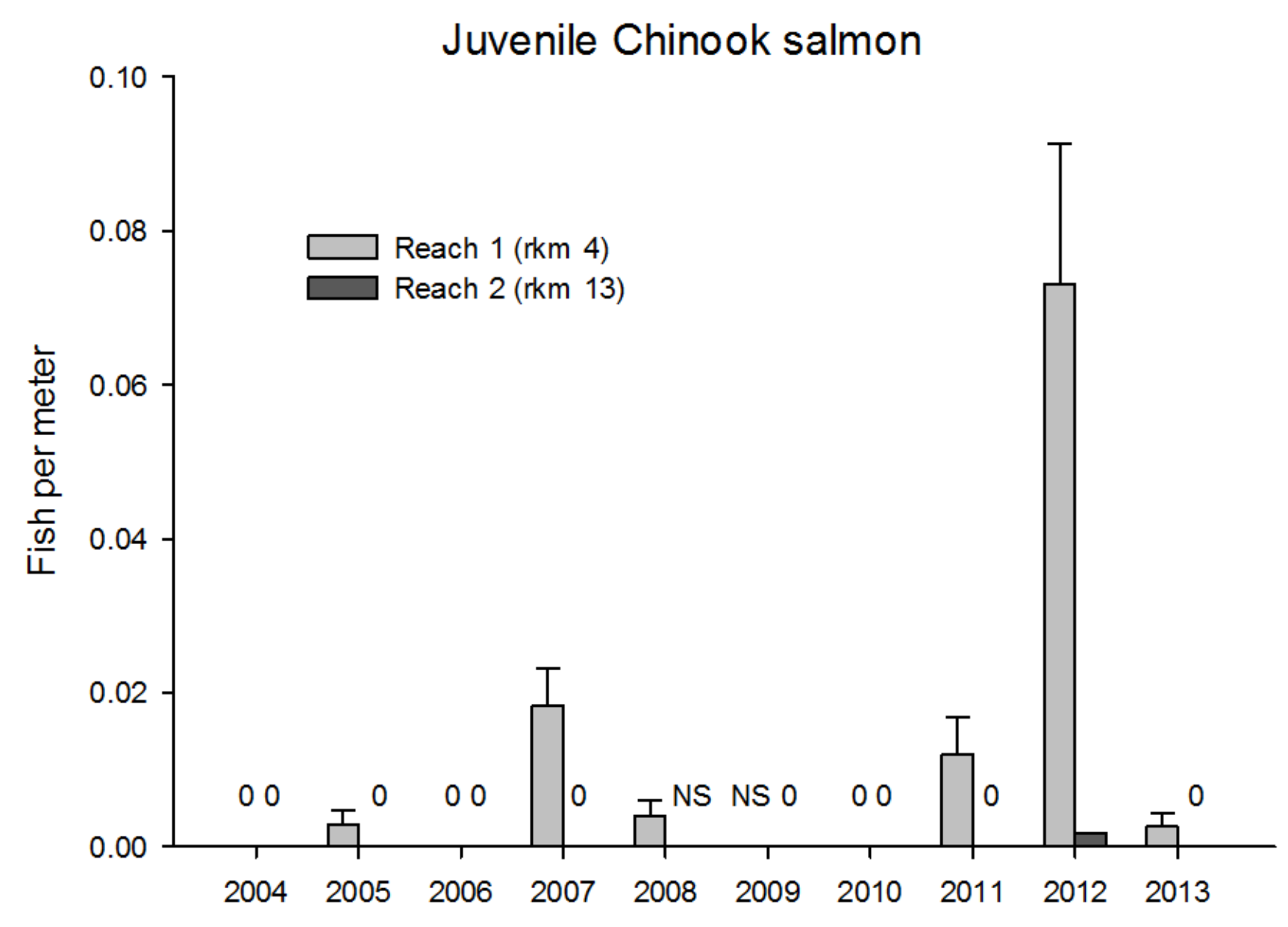

Figure 5. Number of juvenile Chinook per meter in Reaches 1 and 2 of Beaver Creek, Methow River watershed, Washington, 2004-13. NS, not sampled. 

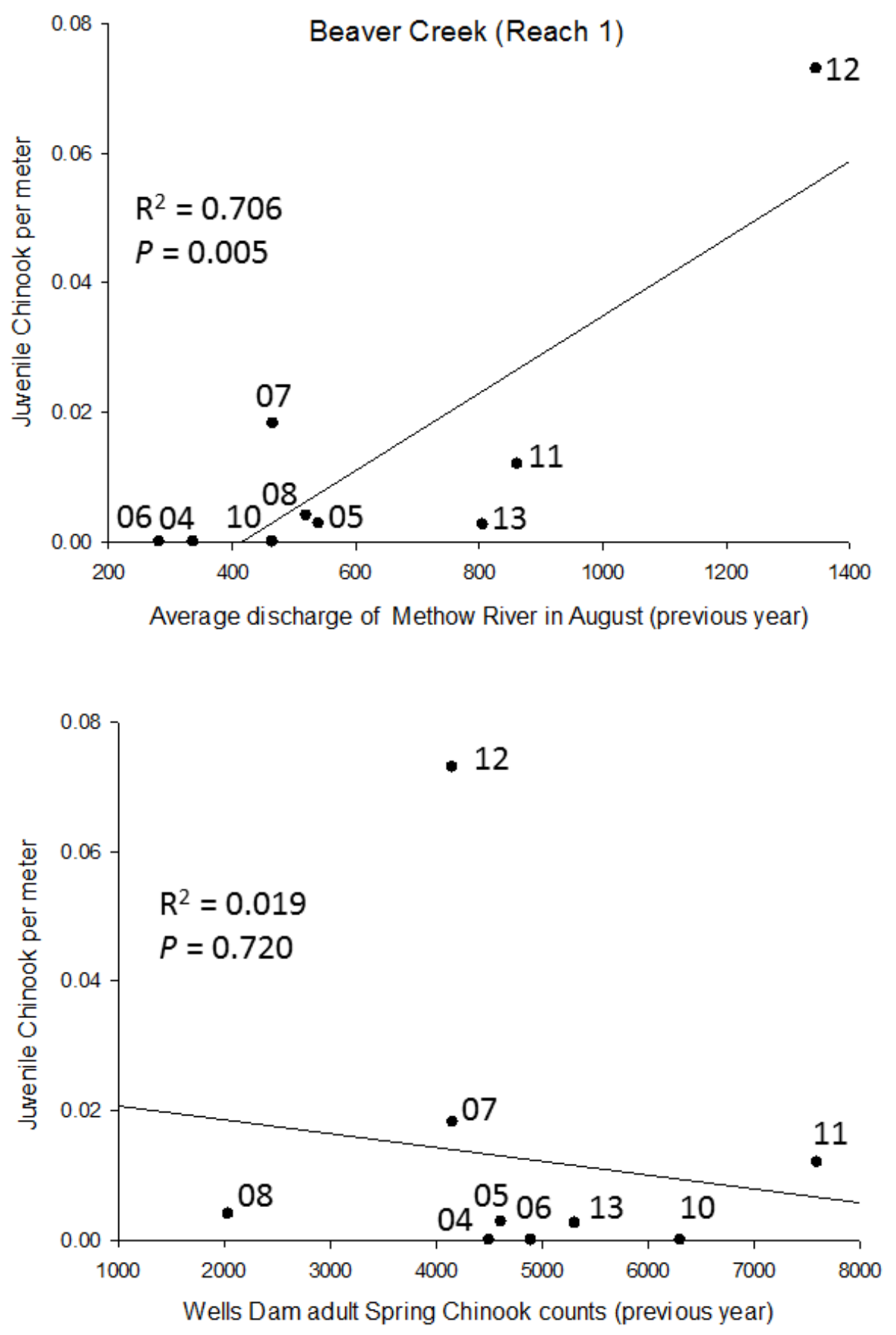

Figure 6. Linear regressions of juvenile Chinook per meter in Reach 1 of Beaver Creek, Methow River watershed, Washington with the average August discharge of Methow River near Pateros flow site from the previous year and number of adult Chinook counted at the Wells Dam adult ladder from the previous year. 


\section{Whitefish Island side channel}

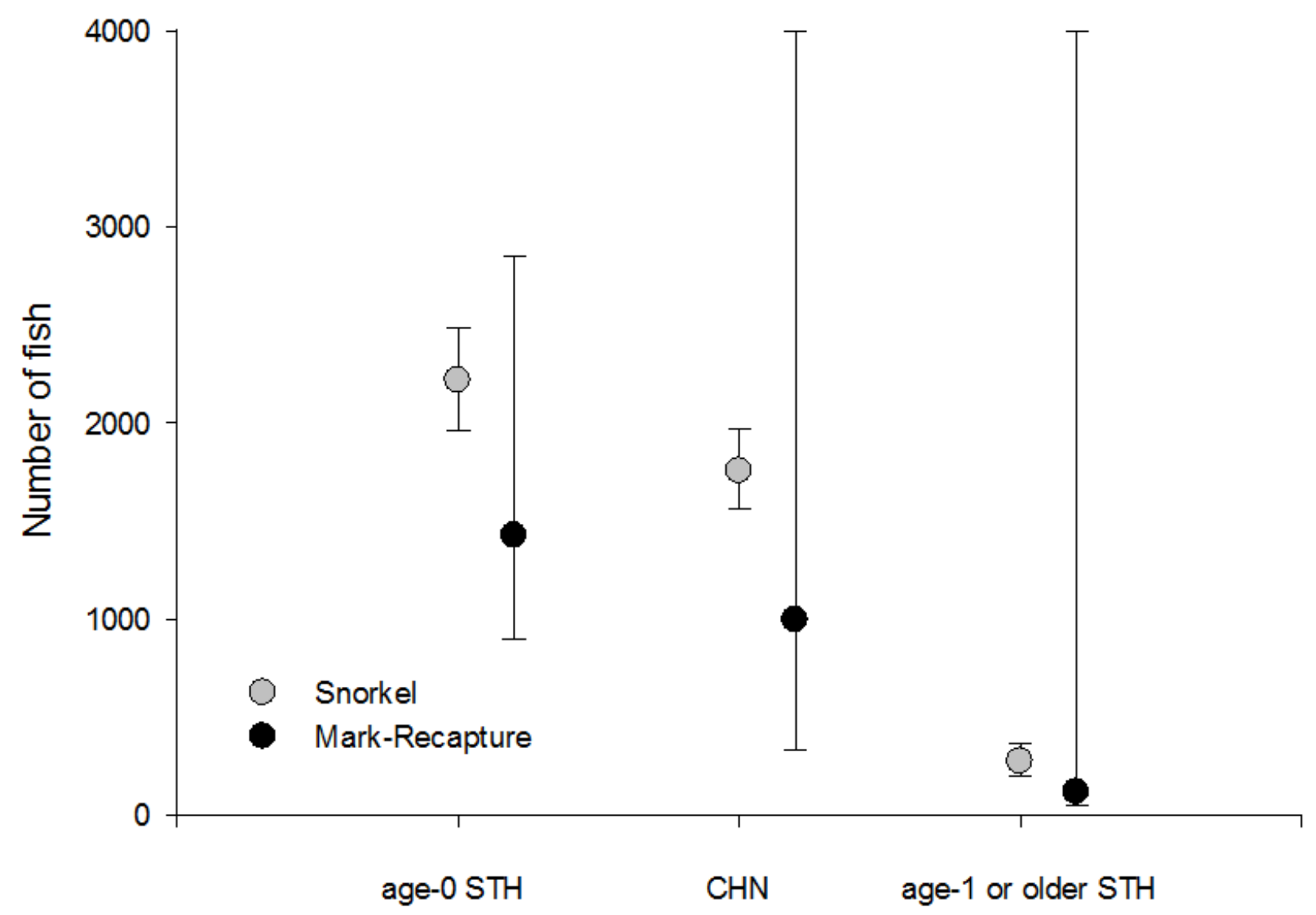

Figure 7. Population abundance estimates from multiple-pass, multiple-unit snorkeling compared to three-pass, mark-recapture electrofishing, Whitefish Island side channel, Methow River watershed, Washington. CHN, Chinook; STH, rainbow trout/steelhead. 


\section{Whitefish Island (age-0 STH)}

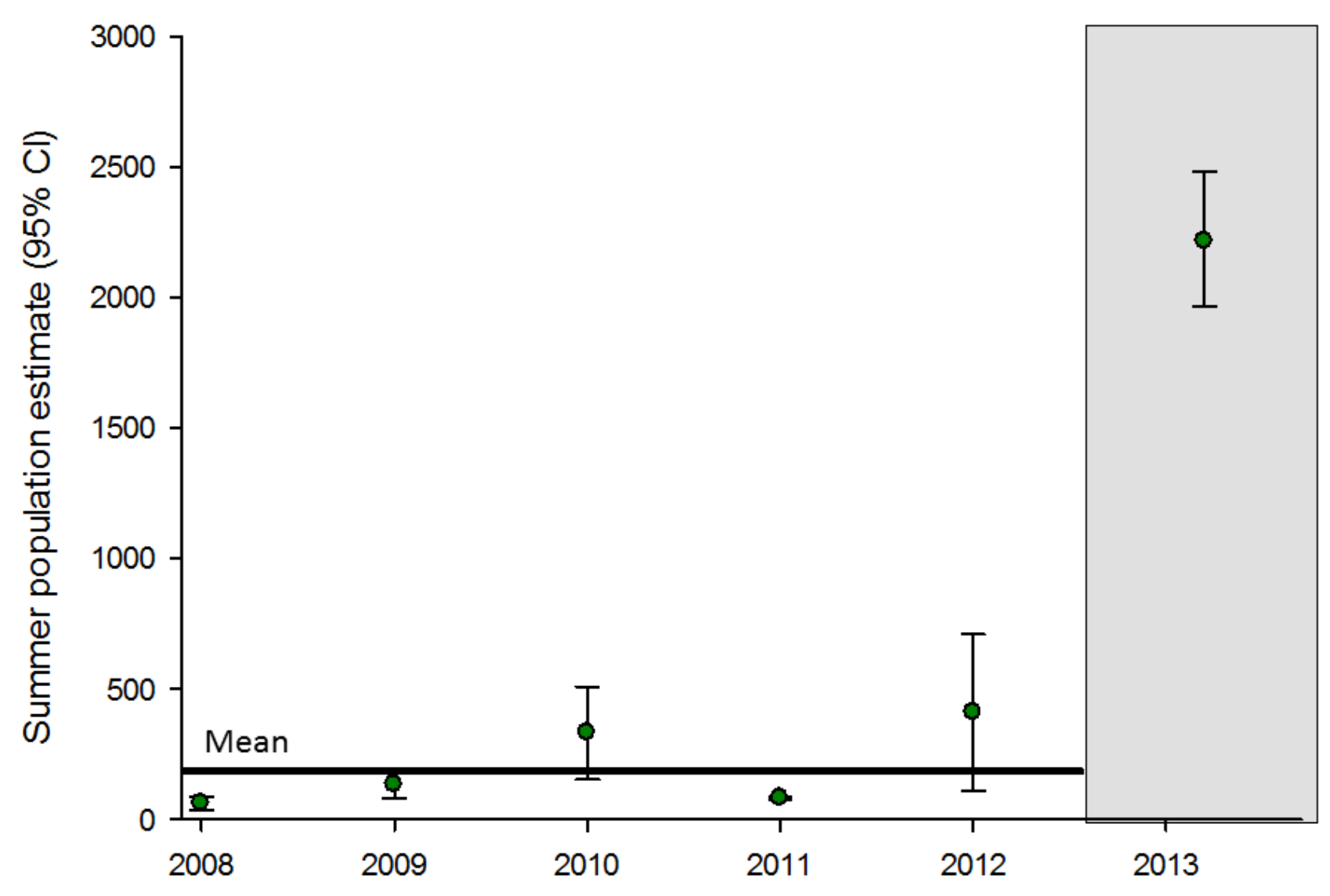

Figure 8. Age-0 rainbow trout/steelhead (STH) population abundance estimate in the Whitefish Island side channel, Methow River watershed, Washington, 2008-13. Cl, confidence interval. Gray box indicates the year sampled post-restoration. 


\section{Whitefish Island (age-1 or older STH)}

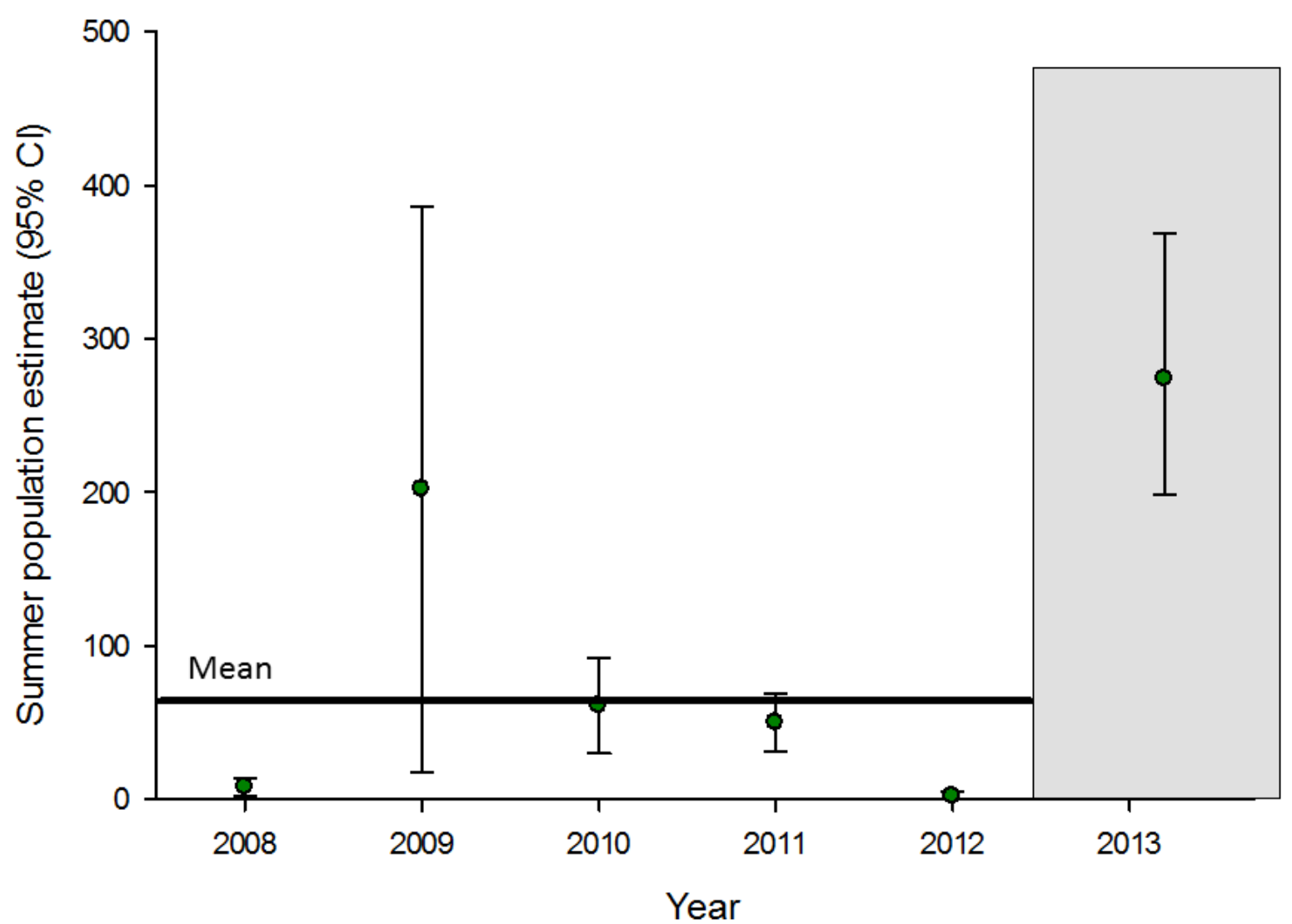

Figure 9. Age-1 or older rainbow trout/steelhead (STH) population abundance estimate in the Whitefish Island side channel, Methow River watershed, Washington, 2008-13. Cl, confidence interval. Gray box indicates the year sampled post-restoration. 


\section{Whitefish Island (Juvenile $\mathrm{CHN}$ )}

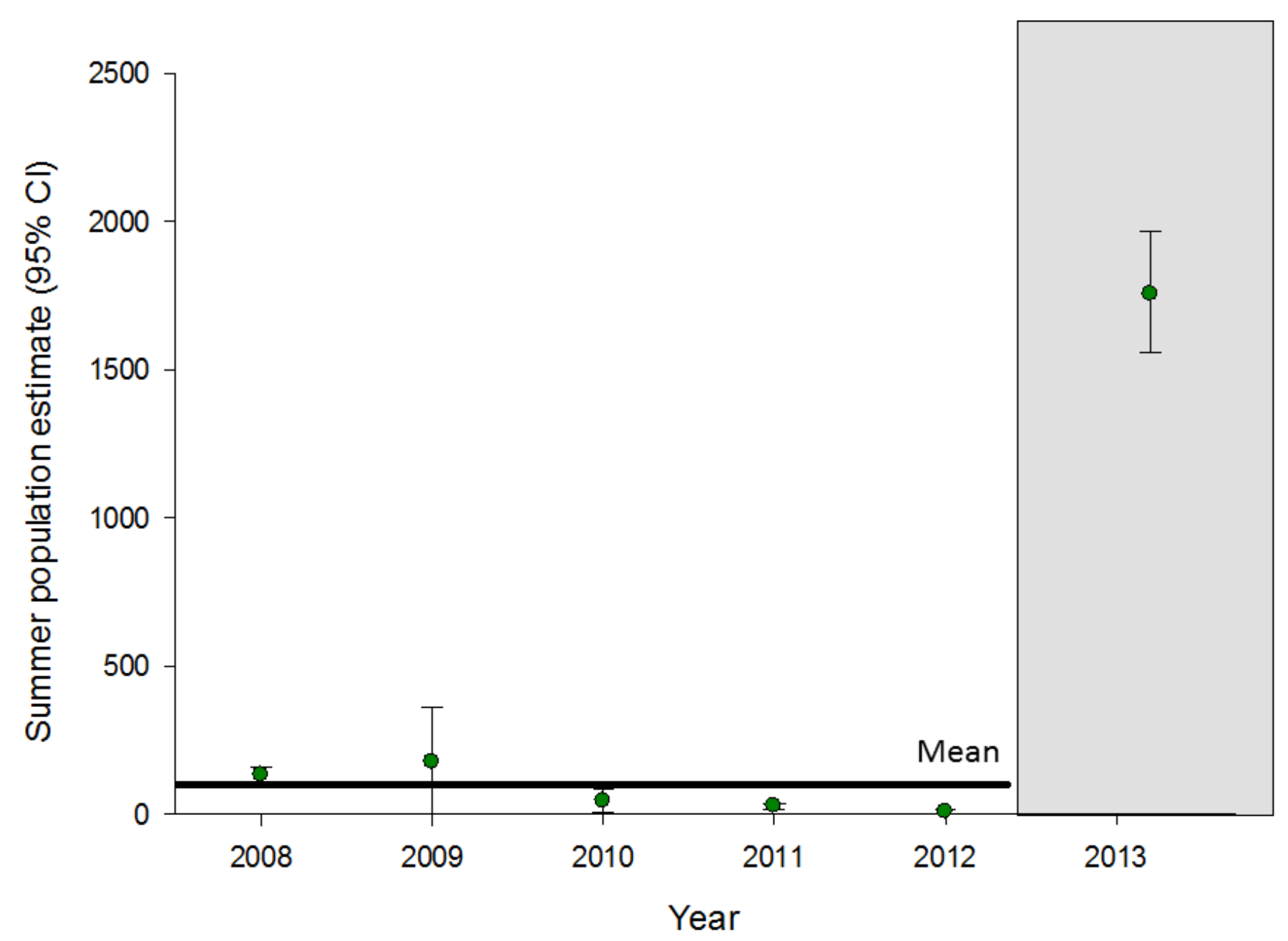

Figure 10. Juvenile Chinook (CHN) population abundance estimate in the Whitefish Island side channel, Methow River watershed, Washington, 2008-13. Cl, confidence interval. Gray box indicates the year sampled post-restoration. 


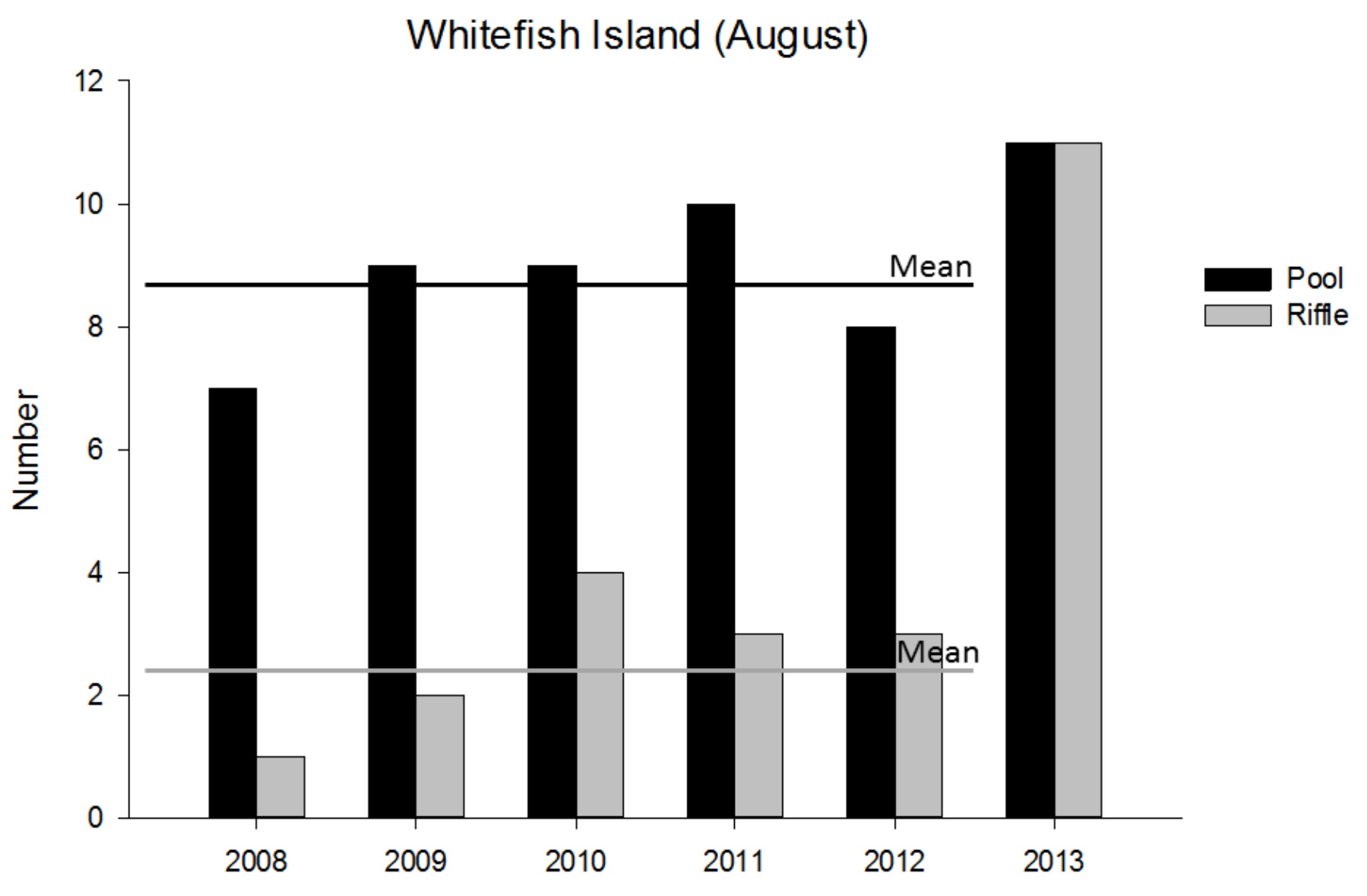

Figure 11. Number of pool and riffle habitat units in the Whitefish Island side channel, Methow River watershed, Washington, before (2008-2012) and after (2013) side channel restoration, following spring high flows. 


\section{Whitefish island (August)}

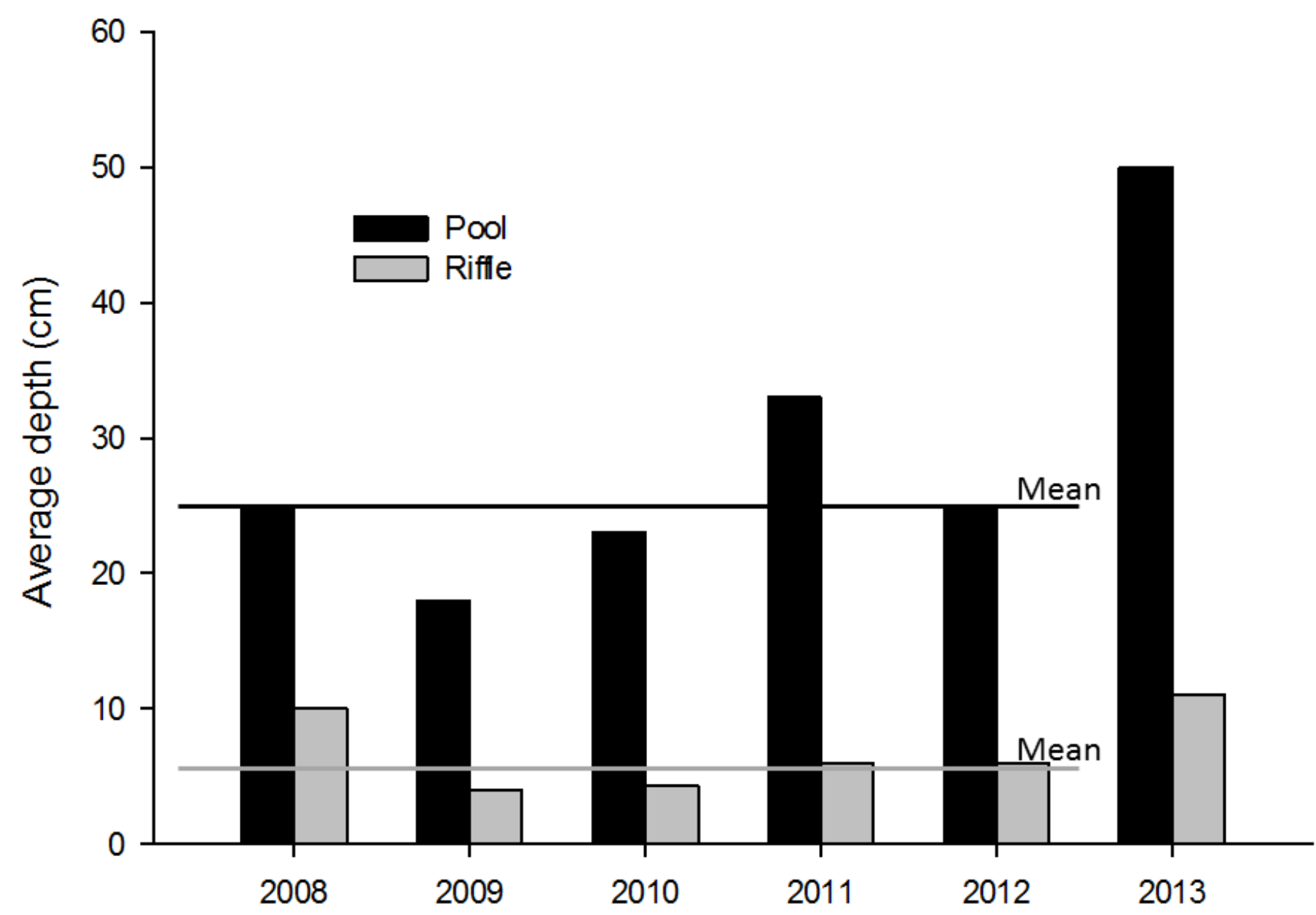

Figure 12. Average depth of pool and riffle habitat units in Whitefish Island side channel, Methow River watershed, Washington, before (2008-12) and after (2013) side channel restoration, following spring high flows. 

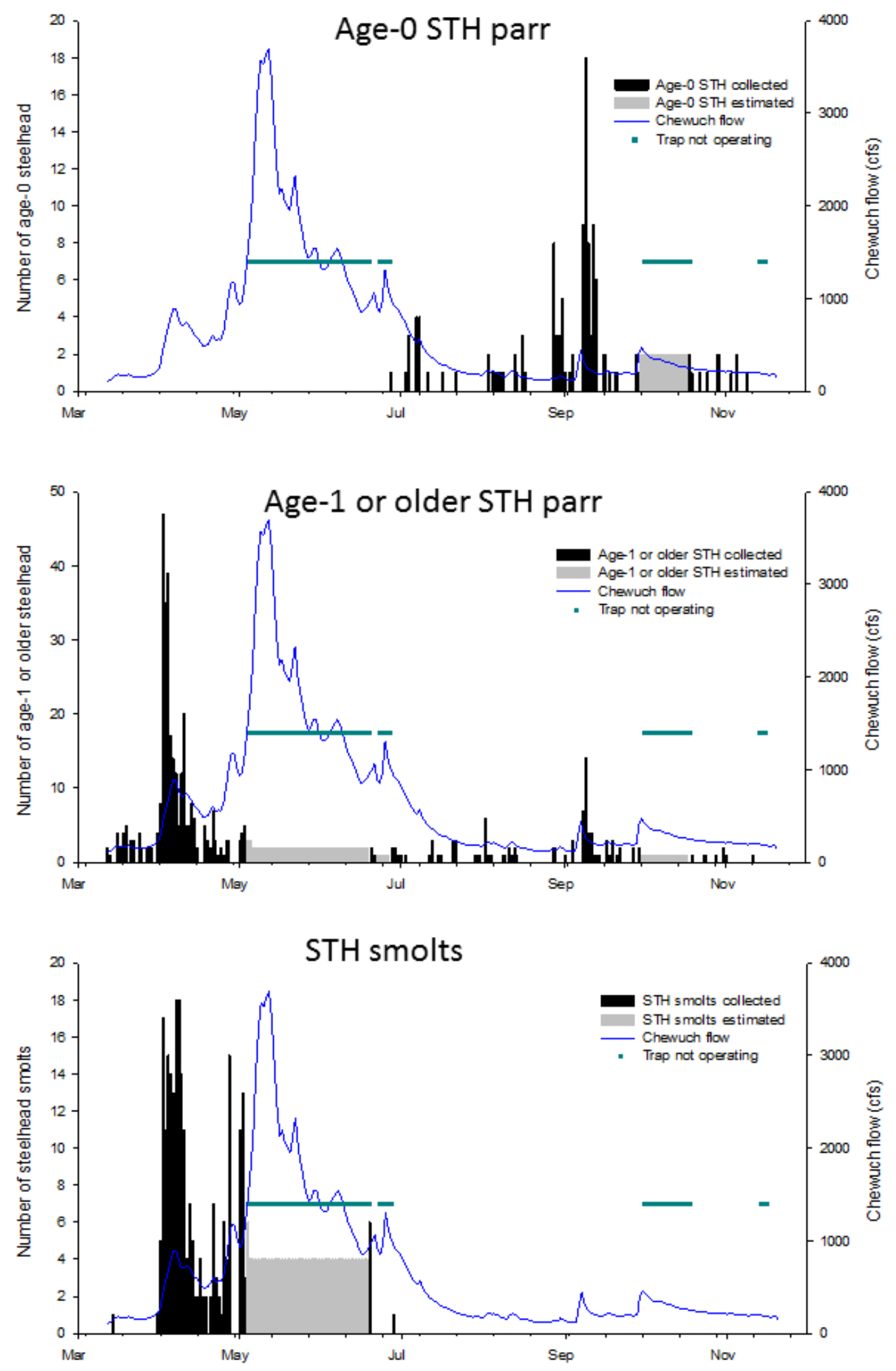

Figure 13. Daily number of rainbow trout/steelhead (STH) collected at the Chewuch River screw trap, Methow River watershed, Washington, 2013. 

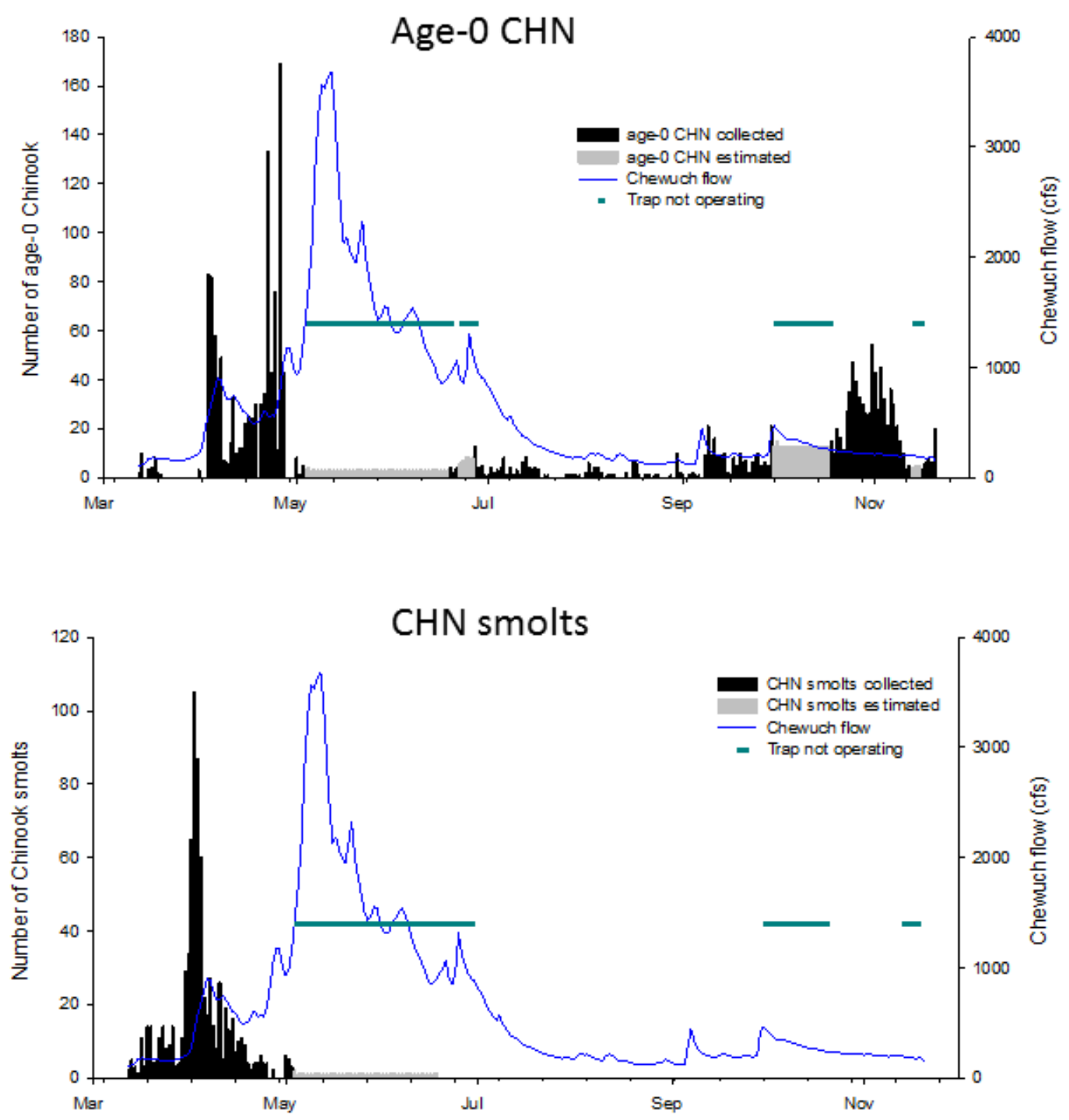

Figure 14. Daily number of juvenile Chinook (CHN) collected at the Chewuch River screw trap, Methow River watershed, Washington, 2013. 


\section{Mainstem Methow PIT tag interrogators}

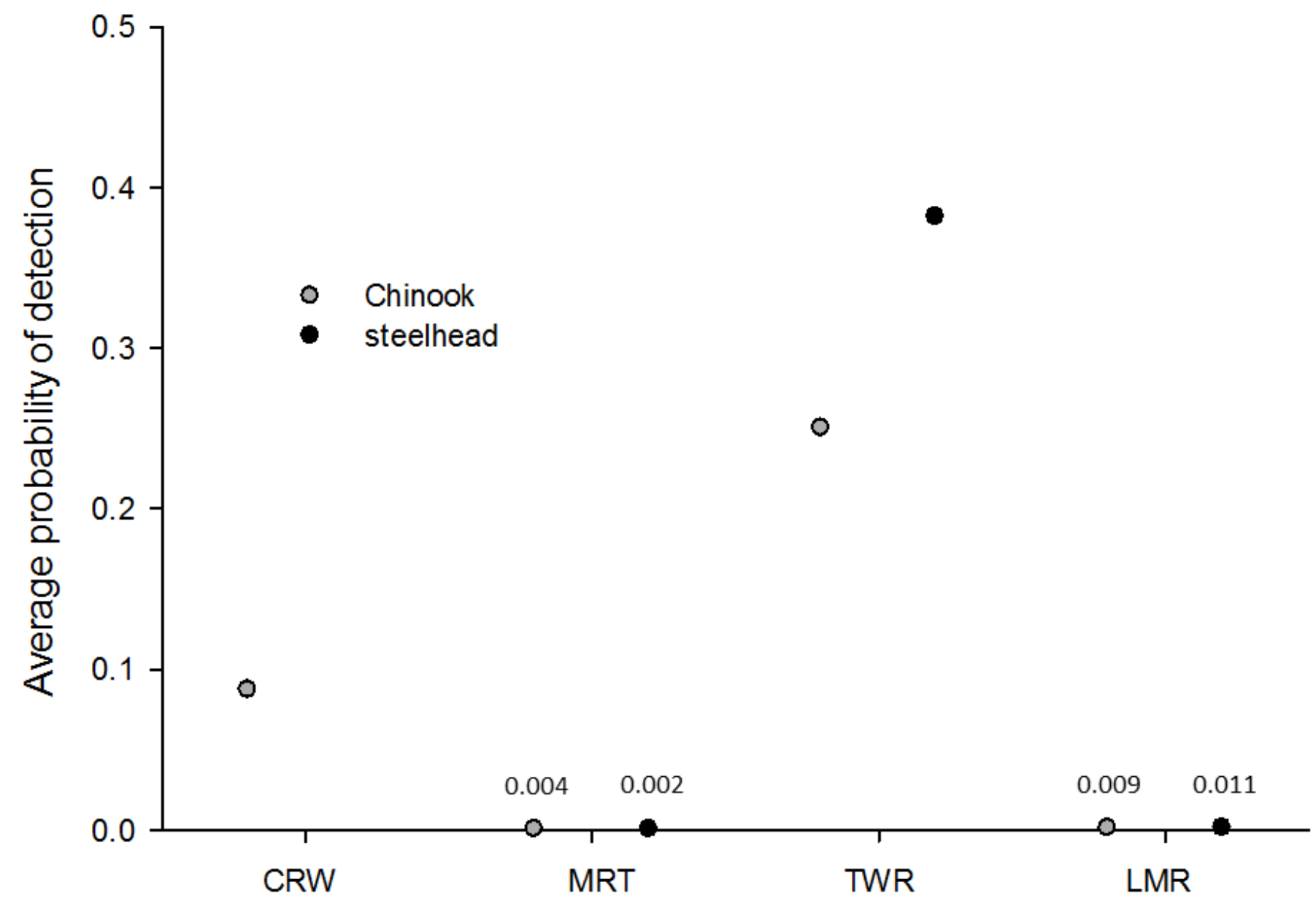

Figure 15. Average probability of detection of hatchery Chinook and steelhead at Methow River PIT tag interrogator in 2013, Methow River watershed, Washington. No hatchery steelhead were released in the Chewuch River. CRW, Chewuch River above Winthrop; LMR, Lower Methow River; MRT, Methow River above Twisp; TWR, Twisp River. 
Table 1. Presence and absence of fish species sampled and/or observed by the U.S. Geological Survey in the mainstem Methow, Chewuch, and Twisp Rivers, and Beaver Creek, Methow River watershed, Washington, 2013.

[Watersheds and streams are listed in a downstream to upstream order within a watershed. A, absent; P, present; km, kilometer]

\begin{tabular}{|c|c|c|c|c|c|c|c|c|c|}
\hline $\begin{array}{l}\text { Watershed } \\
\text { reach or section }\end{array}$ & $\begin{array}{l}\text { Distance } \\
\text { upstream } \\
\text { of mouth } \\
(\mathbf{k m}) \\
\end{array}$ & $\begin{array}{c}\text { Rainbow } \\
\text { trout/steelhead } \\
\text { (Oncorhynchus } \\
\text { mykiss) }\end{array}$ & $\begin{array}{c}\text { Brook } \\
\text { trout } \\
\text { (Salvelinus } \\
\text { fontinalis) } \\
\end{array}$ & $\begin{array}{c}\text { Cutthroat trout } \\
\text { (Oncorhynchus } \\
\text { clarkil) }\end{array}$ & $\begin{array}{c}\text { Chinook } \\
\text { salmon } \\
\text { (Oncorhynchus } \\
\text { tschawytshca) }\end{array}$ & $\begin{array}{c}\text { Coho salmon } \\
\text { (Oncorhynchus } \\
\text { kisutch) }\end{array}$ & $\begin{array}{c}\text { Bull trout } \\
\text { (Salvelinus } \\
\text { confluentus) }\end{array}$ & $\begin{array}{l}\text { Mountain } \\
\text { whitefish } \\
\text { (Prosopium } \\
\text { williamsoni) } \\
\end{array}$ & $\begin{array}{c}\text { Other } \\
\text { species }\end{array}$ \\
\hline \multicolumn{10}{|l|}{ Methow River } \\
\hline Lower Methow & 54.0 & $\mathrm{P}$ & $\mathrm{P}$ & A & $\mathrm{P}$ & $\mathrm{P}$ & A & A & $\mathrm{P}^{3.4 .5}$ \\
\hline Middle Methow & $68.0-76.0$ & & & & & & & & \\
\hline Cannon Beach SC & 68.0 & $\mathrm{P}$ & $\mathrm{A}$ & A & $P$ & $\mathrm{~A}$ & A & A & $\mathrm{P}^{3.4 .5}$ \\
\hline SC2-Habermehl & 70.0 & $\mathrm{P}$ & $\mathrm{P}$ & A & $\mathrm{P}$ & $\mathrm{P}$ & $\mathrm{A}^{1}$ & $\mathrm{~A}^{1}$ & $\mathrm{P}^{3.4 .5}$ \\
\hline WDFW SC & 72.0 & $\mathrm{P}$ & A & A & $\mathrm{P}$ & $\mathrm{P}$ & A & A & $\mathrm{P}^{3.4 .5}$ \\
\hline SC3-Whitefish Island & 76.0 & $P$ & $\mathrm{P}$ & A & $P$ & $\mathrm{P}$ & $\mathrm{P}$ & A & $\mathrm{P}^{3.4,5}$ \\
\hline Upper Methow & 94.0 & $\mathrm{P}$ & $\mathrm{P}$ & A & $\mathrm{P}$ & A & A & $\mathrm{A}$ & A \\
\hline \multicolumn{10}{|l|}{ Twisp River } \\
\hline Elbow Coulee & 10.0 & $\mathrm{P}$ & $\mathrm{P}$ & A & $\mathrm{P}$ & $\mathrm{P}$ & A & A & $\mathrm{P}^{3,5}$ \\
\hline \multicolumn{10}{|l|}{ Chewuch River } \\
\hline Chewuch screw trap & 1.0 & $\mathrm{P}$ & $\mathrm{P}^{2}$ & $\mathrm{P}$ & $\mathrm{P}$ & $\mathrm{A}^{1}$ & $\mathrm{P}$ & $\mathrm{P}$ & $\mathrm{P}^{3,4,5,6}$ \\
\hline \multicolumn{10}{|l|}{ Beaver Creek } \\
\hline Reach 1 & 4.6 & $\mathrm{P}$ & $\mathrm{P}$ & A & $\mathrm{P}^{2}$ & $\mathrm{P}$ & A & A & $\mathrm{P}^{3}$ \\
\hline Reach 2 & 13.0 & $\mathrm{P}$ & $\mathrm{P}$ & $A^{1}$ & $\mathrm{~A}^{1}$ & $\mathrm{~A}$ & $A^{1}$ & A & $\mathrm{P}^{3}$ \\
\hline Reach 4 & 16.0 & $\mathrm{P}$ & $P$ & $\mathrm{P}^{2}$ & A & A & $\mathrm{A}^{1}$ & A & A \\
\hline \multicolumn{10}{|c|}{${ }^{2}$ Species was detected during previous years of sampling, but were not observed during 2013 sampling. } \\
\hline
\end{tabular}


Table 2. Streams surveyed or sampled for fish and locations of 4,018 passive integrated transponder (PIT) tags deployed in the Methow River watershed, Washington, 2013.

[Watersheds and streams are listed in a downstream to upstream order within a watershed. Method surveyed: FSNP, fish sampled by electrofishing, not a population survey; PS, 500-m reach population survey; RST, rotary screw trap. Species codes: BLS, bridgelip sucker; BLT, bull trout; CHN, Chinook; COH, coho; CTT, cutthroat trout; LND, longnose dace; RBT, juvenile rainbow trout/steelhead ; STH, adult steelhead; WHT, mountain whitefish; km, kilometer]

\begin{tabular}{|c|c|c|c|c|c|c|c|c|c|c|c|}
\hline \multirow[b]{2}{*}{$\begin{array}{c}\text { Watershed } \\
\text { side channel (SC) }\end{array}$} & \multirow{2}{*}{$\begin{array}{l}\text { Distance } \\
\text { upstream } \\
\text { of mouth } \\
(\mathbf{k m})\end{array}$} & \multirow[b]{2}{*}{$\begin{array}{l}\text { Method } \\
\text { surveyed }\end{array}$} & \multicolumn{9}{|c|}{ Total number of 134.2 kiloHertz (kHz) PIT tags deployed } \\
\hline & & & RBT & STH & CTT & CHN & $\mathrm{COH}$ & BLT & BLS & WHT & LND \\
\hline \multicolumn{12}{|l|}{ Methow River } \\
\hline $\begin{array}{l}\text { Lower Methow } \\
\text { Middle Methow }\end{array}$ & $\begin{array}{l}54.0 \\
68.0-76.0\end{array}$ & FSNP & 40 & 0 & 0 & 12 & 5 & 0 & 16 & 0 & 0 \\
\hline Cannon Beach SC & 68.0 & FSNP & 3 & 0 & 0 & 5 & 0 & 0 & 0 & 0 & 0 \\
\hline SC2- Habermehl & 70.0 & FSNP & 24 & 0 & 0 & 13 & 9 & 0 & 6 & 0 & 0 \\
\hline WDFW SC & 72.0 & FSNP & 11 & 0 & 0 & 54 & 39 & 0 & 0 & 0 & 0 \\
\hline SC3-Whitefish Is. & 76.0 & PS & 190 & 0 & 0 & 104 & 6 & 2 & 4 & 0 & 0 \\
\hline Upper Methow & 94.0 & FSNP & 3 & 0 & 0 & 7 & 0 & 0 & 0 & 0 & 0 \\
\hline \multicolumn{12}{|l|}{ Twisp River } \\
\hline Elbow Coulee & 10.0 & FSNP & 27 & 0 & 0 & 1 & 20 & 0 & 0 & 0 & 0 \\
\hline \multicolumn{12}{|l|}{ Chewuch River } \\
\hline Chewuch screw trap & 1.0 & RST & 727 & 0 & 17 & 1,596 & 0 & 5 & 39 & 29 & 518 \\
\hline \multicolumn{12}{|l|}{ Beaver Creek } \\
\hline Reach 1 & 4.6 & PS,FSNP & 277 & 0 & 0 & 1 & 3 & 0 & 0 & 0 & 0 \\
\hline Reach 2 & 13.0 & PS,FSNP & 145 & 0 & 0 & 0 & 0 & 0 & 0 & 0 & 0 \\
\hline \multirow[t]{2}{*}{ Reach 4} & 16.0 & PS,FSNP & 59 & 0 & 1 & 0 & 0 & 0 & 0 & 0 & 0 \\
\hline & & Total & 1,506 & $\mathbf{0}$ & 18 & 1,793 & 82 & 7 & 65 & 29 & 518 \\
\hline
\end{tabular}


Table 3. Streams surveyed or sampled for fish and locations of nine genetic samples collected in the Methow River watershed, Washington, 2013.

[Watersheds and streams are listed in a downstream to upstream order within a watershed. Species codes: BLT, bull trout; $\mathrm{COH}$, coho; km, kilometer]

\begin{tabular}{lccc}
\hline \multicolumn{1}{c}{$\begin{array}{c}\text { Watershed } \\
\text { stream reach or section }\end{array}$} & $\begin{array}{c}\text { Distance upstream } \\
\text { of mouth } \\
(\mathbf{k m})\end{array}$ & COH & BLT \\
\hline $\begin{array}{l}\text { Methow River } \\
\text { Middle Methow }\end{array}$ & & & \\
SC3-Whitefish Island & 76.0 & 1 & 2 \\
Chewuch River & & & \\
Chewuch screw trap & 1.0 & 0 & 5 \\
Beaver Creek & & & \\
Reach 1 & 4.6 & 1 & 0 \\
\hline
\end{tabular}


Table 4. Passive integrated transponder (PIT) tag interrogation sites and total number of fish detected by species, Methow River watershed, Washington, 2013.

[Watersheds and streams are listed in a downstream to upstream order within a watershed. Species codes: BLT, bull trout; BRK, brook trout; BVR, beaver; CHN, Chinook; CHNa, adult Chinook; $\mathrm{COH}$, coho; COHa, adult coho; CTT, cutthroat trout; LND, longnose dace; RBT, juvenile rainbow trout/steelhead; STH, adult steelhead; WHT, mountain whitefish; km, kilometer]

\begin{tabular}{|c|c|c|c|c|c|c|c|c|c|c|c|c|c|}
\hline \multirow[b]{2}{*}{$\begin{array}{l}\text { Watershed } \\
\text { site }\end{array}$} & \multirow[b]{2}{*}{$\begin{array}{l}\text { Distance } \\
\text { upstream } \\
\text { of mouth } \\
(\mathrm{km})\end{array}$} & \multirow[b]{2}{*}{$\begin{array}{l}\text { Interrogator } \\
\text { install date }\end{array}$} & \multirow[b]{2}{*}{ BLT } & \multirow[b]{2}{*}{ BRK } & \multirow[b]{2}{*}{$\begin{array}{l}\text { Juv. } \\
\text { CHN }\end{array}$} & \multirow[b]{2}{*}{$\begin{array}{l}\text { Adult } \\
\text { CHNa }\end{array}$} & \multicolumn{6}{|c|}{ Total number of 134.2 kiloHertz (kHz) PIT tags detected } & \multirow[b]{2}{*}{ WHT } \\
\hline & & & & & & & $\begin{array}{l}\text { Juv. } \\
\text { COH }\end{array}$ & $\begin{array}{l}\text { Adult } \\
\mathrm{COH}\end{array}$ & CTT & LND & RBT & STH & \\
\hline \multicolumn{14}{|l|}{ Methow River } \\
\hline Middle Methow (MRT) ${ }^{1}$ & 65.2 & 2009 & 5 & 0 & 43 & 12 & 0 & 0 & 2 & 0 & 17 & 71 & 35 \\
\hline Upper Methow (MRW) ${ }^{12}$ & 85.0 & 2009 & 3 & 0 & 34 & 62 & 0 & 0 & 2 & 35 & 2 & 11 & 1 \\
\hline \multicolumn{14}{|l|}{ Twisp Watershed } \\
\hline Little Bridge Creek (LBT) $^{1}$ & 1.0 & 2013 & 3 & 0 & 0 & 2 & 0 & 0 & 1 & 0 & 50 & 0 & 0 \\
\hline Chewuch River $(\mathbf{C R W})^{13}$ & 1.5 & 2010 & 3 & 0 & 608 & 85 & 0 & 0 & 6 & 63 & 160 & 84 & 5 \\
\hline \multicolumn{14}{|l|}{ Beaver Creek } \\
\hline Lower $(\mathrm{BVC})^{1}$ & 5.0 & 2004 & 1 & 1 & 2 & 0 & 2 & 0 & 0 & 0 & 112 & 14 & 0 \\
\hline Upper & 12.0 & 2005 & 0 & 0 & 0 & 1 & 0 & 0 & 0 & 0 & 24 & 3 & 0 \\
\hline
\end{tabular}


Table 5. Results of the top 10 models ranked by $\triangle \mathrm{AIC}$ for $\mathrm{N}$-mixture models completed through multiple-pass multiple-unit snorkeling, Methow River watershed, Washington.

[Abundance model covariates: Area, habitat unit area; Type, habitat unit type; Adepth, average depth; ., no covariate. Model type: ZIP, Zero Inflated Poisson]

\begin{tabular}{|c|c|c|c|c|c|}
\hline Detection model & Abundance model & $\begin{array}{c}\text { Model } \\
\text { type }\end{array}$ & AIC & $\triangle \mathrm{AlC}$ & $\begin{array}{c}\text { Population } \\
\text { estimate }\end{array}$ \\
\hline \multicolumn{6}{|c|}{ Rainbow trout/steelhead age- 0} \\
\hline Area+Type+Adepth+Adepth ${ }^{2}$ & Area+Area ${ }^{2}+$ Type+Adepth & ZIP & 1,341 & 0 & 2,216 \\
\hline Area+Type + Adepth + Adepth $^{2}$ & Type+Adepth+Adepth ${ }^{2}$ & ZIP & 1,361 & 20 & 2,606 \\
\hline Area+Type+Adepth+Adepth ${ }^{2}$ & Area + Type + Adepth + Adepth $^{2}$ & ZIP & 1,362 & 21 & 2,644 \\
\hline Area+Type+Adepth+Adepth ${ }^{2}$ & Type+Adepth+Adepth ${ }^{2}$ & ZIP & 1,363 & 22 & 2,371 \\
\hline Area+Type + Adepth + Adepth $^{2}$ & Type & ZIP & 1,373 & 33 & 2,802 \\
\hline Area+Type + Adepth + Adepth $^{2}$ & Type+Adepth & ZIP & 1,373 & 33 & 2,765 \\
\hline Area+Type + Adepth + Adepth $^{2}$ & Area+Type & ZIP & 1,374 & 33 & 2,777 \\
\hline Area+Type+Adepth & Area + Type + Adepth + Adepth $^{2}$ & ZIP & 1,393 & 52 & 2,014 \\
\hline Area+Type + Adepth + Adepth $^{2}$ & Adepth & ZIP & 1,403 & 62 & 1,830 \\
\hline Area+Type+Adepth+Adepth ${ }^{2}$ & Adepth+Adepth ${ }^{2}$ & ZIP & 1,405 & 64 & 1,760 \\
\hline \multicolumn{6}{|c|}{ Juvenile Chinook } \\
\hline Area+Type+Adepth+Adepth ${ }^{2}$ & Adepth+Adepth ${ }^{2}$ & ZIP & 669 & 0 & 1,755 \\
\hline 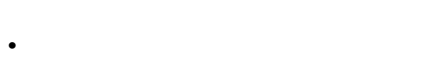 & Area + Type + Adepth + Adepth $^{2}$ & ZIP & 670 & 1 & 1,644 \\
\hline • & Adepth+Adepth ${ }^{2}$ & ZIP & 671 & 2 & 1,630 \\
\hline Area+Type+Adepth & Adepth+Adepth ${ }^{2}$ & ZIP & 672 & 3 & 2,053 \\
\hline Type & Adepth+Adepth ${ }^{2}$ & ZIP & 672 & 3 & 1,672 \\
\hline Area+Type + Adepth + Adepth $^{2}$ & Type+Adepth & ZIP & 673 & 4 & 2,023 \\
\hline Area+Type+Adepth+Adepth ${ }^{2}$ & Adepth & ZIP & 673 & 4 & 3,370 \\
\hline Area+Type + Adepth + Adepth $^{2}$ & Area & ZIP & 673 & 4 & 4,070 \\
\hline Area+Type+Adepth + Adepth $^{2}$ & Area + Adepth + Adepth ${ }^{2}$ & ZIP & 673 & 4 & 1,828 \\
\hline Area+Type+Adepth & Adepth & ZIP & 674 & 5 & 3,139 \\
\hline \multicolumn{6}{|c|}{ Rainbow trout/steelhead age-1 or older } \\
\hline Area+Type+Adepth & Adepth & ZIP & 250 & 0 & 274 \\
\hline Area+Type+Adepth & Area & ZIP & 251 & 1 & 432 \\
\hline Area+Type+Adepth & Type & ZIP & 252 & 2 & 191 \\
\hline Area+Type + Adepth & Area+Adepth & ZIP & 252 & 2 & 236 \\
\hline Area+Type+Adepth & Type+Adepth & ZIP & 252 & 2 & 1,351 \\
\hline Area+Type & Area+Type+Adepth & ZIP & 252 & 2 & 1,330 \\
\hline Area+Type+Adepth & Area+Type & ZIP & 253 & 3 & 265 \\
\hline - & Area+Type+Adepth & ZIP & 253 & 3 & 196 \\
\hline Area+Type+Adepth & Area+Type + Adepth & ZIP & 254 & 4 & 1,364 \\
\hline Type+Adepth & Adepth & ZIP & 254 & 4 & 341 \\
\hline
\end{tabular}


Table 6. Population estimates from Chewuch River screw trap, Methow River watershed, Washington, 2013.

[LCI, lower confidence interval; UCI, upper confidence interval]

\begin{tabular}{lcccc}
\hline \multicolumn{1}{c}{ Species and age-class } & $\begin{array}{c}\text { Number } \\
\text { tagged }\end{array}$ & $\begin{array}{c}\text { Population } \\
\text { estimate }\end{array}$ & $\begin{array}{c}95 \text { percent } \\
\text { LCl }\end{array}$ & $\begin{array}{c}95 \text { percent } \\
\text { UCl }\end{array}$ \\
\hline Chinook - age-0 & 2,139 & 44,019 & 27,856 & 60,182 \\
Chinook - smolts & 764 & 15,494 & 10,786 & 20,201 \\
Total & & $\mathbf{5 9 , 5 1 3}$ & & \\
& 123 & 1,687 & 1,185 & 2,188 \\
Steelhead - age-0 & 416 & 18,337 & 10,322 & 26,431 \\
Steelhead - age-1 or older & 239 & 15,227 & 9,636 & 20,817 \\
Steelhead - smolts & & $\mathbf{3 5 , 2 9 0}$ & & \\
Total & & & & \\
\hline
\end{tabular}




\section{Appendix}

Table A1. Average weekly length in millimeters and (number) of common salmonid species collected in the Chewuch River screw trap, Methow River watershed, Washington, 2013.

[Species codes: CHN, juvenile Chinook; STH, juvenile rainbow trout/steelhead; --, no fish were available for capture; TNP, Trap not operating]

\begin{tabular}{|c|c|c|c|c|c|}
\hline Week & $\begin{array}{c}\text { Age-0 } \\
\text { STH }\end{array}$ & $\begin{array}{l}\text { Age-1 or } \\
\text { older STH }\end{array}$ & $\begin{array}{c}\text { Smolt } \\
\text { STH }\end{array}$ & $\begin{array}{l}\text { Age-0 } \\
\text { CHN }\end{array}$ & $\begin{array}{l}\text { Smolt } \\
\text { CHN }\end{array}$ \\
\hline March 11 & -- & $89(13)$ & $115(1)$ & $34(29)$ & $92(39)$ \\
\hline March 18 & -- & $95(17)$ & -- & $33(1)$ & $92(65)$ \\
\hline March 25 & -- & $90(18)$ & $167(6)$ & $36(3)$ & $95(160)$ \\
\hline April 1 & -- & $83(169)$ & $154(106)$ & $34(318)$ & $90(332)$ \\
\hline April 8 & -- & $85(58)$ & $150(45)$ & $33(109)$ & $86(94)$ \\
\hline April 15 & -- & $80(20)$ & $157(19)$ & $33(276)$ & $84(44)$ \\
\hline April 22 & -- & $83(10)$ & $164(28)$ & $34(352)$ & $89(16)$ \\
\hline April 29 & -- & $83(12)$ & $155(27)$ & $35(14)$ & $87(14)$ \\
\hline May 6 & TNP & TNP & TNP & TNP & TNP \\
\hline May 13 & TNP & TNP & TNP & TNP & TNP \\
\hline May 20 & TNP & TNP & TNP & TNP & TNP \\
\hline May 27 & TNP & TNP & TNP & TNP & TNP \\
\hline June 3 & TNP & TNP & TNP & TNP & TNP \\
\hline June 10 & TNP & TNP & TNP & TNP & TNP \\
\hline June 17 & -- & $158(3)$ & $129(6)$ & $47(10)$ & -- \\
\hline June 24 & $25(1)$ & $98(4)$ & $160(1)$ & $51(22)$ & -- \\
\hline July 1 & $26(4)$ & $114(3)$ & -- & $53(15)$ & -- \\
\hline July 8 & $33(7)$ & $172(1)$ & -- & $57(24)$ & -- \\
\hline July 15 & $38(1)$ & $164(5)$ & -- & $64(23)$ & -- \\
\hline July 22 & $43(1)$ & $193(6)$ & -- & $85(2)$ & -- \\
\hline July 29 & -- & $142(9)$ & -- & $81(12)$ & -- \\
\hline August 5 & $54(7)$ & $161(3)$ & -- & $82(14)$ & -- \\
\hline August 12 & $60(6)$ & $178(6)$ & -- & $89(10)$ & -- \\
\hline August 19 & $64(1)$ & -- & -- & $94(10)$ & -- \\
\hline August 26 & $69(14)$ & $194(2)$ & -- & $98(12)$ & -- \\
\hline September 2 & $73(9)$ & $210(4)$ & -- & $89(8)$ & -- \\
\hline September 9 & $80(53)$ & $144(31)$ & -- & $84(73)$ & -- \\
\hline September 16 & $79(4)$ & $166(8)$ & -- & $93(42)$ & -- \\
\hline September 23 & $82(1)$ & $151(5)$ & -- & $91(44)$ & -- \\
\hline September 30 & $87(3)$ & $180(1)$ & -- & $85(26)$ & -- \\
\hline October 7 & TNP & TNP & TNP & TNP & TNP \\
\hline October 14 & 99(3) & -- & -- & $83(15)$ & -- \\
\hline October 21 & $86(2)$ & $176(2)$ & -- & $88(166)$ & -- \\
\hline October 28 & $92(3)$ & $190(4)$ & -- & $87(251)$ & -- \\
\hline November 4 & $81(1)$ & -- & -- & $83(213)$ & -- \\
\hline November 11 & -- & $159(1)$ & -- & $82(33)$ & -- \\
\hline November 18 & -- & -- & -- & $90(43)$ & -- \\
\hline
\end{tabular}


Table A2. Probability of survival and detection probability for hatchery released fish in the Methow River watershed, Washington, 2013.

[Abbreviations: STH , juvenile steelhead; CHN, juvenile Chinook. N, number; SE, Standard error; LCI, 95 percent lower confidence interval; UCL, 95 percent upper confidence interval; REL, release site; CRW, Chewuch River above Winthrop; LMR, Lower Methow River; MCN, McNary Dam, RRE, Rocky Reach Dam, JDA, John Day Dam, BON, Bonneville Dam, ALL, all site combined, TWL, Columbia River Trawl, MRT, Methow River above Twisp, ]

\begin{tabular}{|c|c|c|c|c|c|c|c|c|c|c|c|c|}
\hline \multirow[b]{2}{*}{ Release site } & \multirow[b]{2}{*}{ species } & \multirow[b]{2}{*}{ tags } & \multicolumn{5}{|c|}{ Survival estimates } & \multicolumn{5}{|c|}{ Detection estimates } \\
\hline & & & Section & $\mathbf{N}$ & SE & $\mathrm{LCl}$ & $\mathrm{UCl}$ & Site & $\mathbf{N}$ & SE & $\mathrm{LCl}$ & $\mathrm{UCl}$ \\
\hline \multirow[t]{7}{*}{ Chewuch } & \multirow[t]{7}{*}{$\mathrm{CHN}$} & \multirow[t]{7}{*}{5,000} & REL to CRW & 1.000 & 0.000 & 1.000 & 1.000 & CRW & 0.087 & 0.000 & 0.080 & 0.095 \\
\hline & & & CRW to LMR & 0.670 & 0.033 & 0.603 & 0.730 & LMR & 0.001 & 0.001 & 0.000 & 0.003 \\
\hline & & & LMR to RRE & 1.000 & 0.000 & 0.000 & 1.000 & RRE & 0.370 & 0.019 & 0.332 & 0.409 \\
\hline & & & RRE to $\mathrm{MCN}$ & 0.938 & 0.152 & 0.084 & 1.000 & $\mathrm{MCN}$ & 0.104 & 0.017 & 0.075 & 0.143 \\
\hline & & & $\mathrm{MCN}$ to JDA & 0.643 & 0.183 & 0.274 & 0.895 & JDA & 0.098 & 0.024 & 0.060 & 0.157 \\
\hline & & & JDA to BON & 1.000 & 0.031 & 0.000 & 1.000 & $\mathrm{BON}$ & 0.042 & 0.040 & 0.025 & 0.069 \\
\hline & & & REL to TWL & 0.849 & 0.007 & 0.835 & 0.863 & ALL & 0.120 & 0.004 & 0.113 & 0.128 \\
\hline \multirow[t]{7}{*}{ MDVAP } & \multirow[t]{7}{*}{$\mathrm{CHN}$} & \multirow[t]{7}{*}{5,980} & REL to MRT & 1.000 & 0.019 & 0.000 & 1.000 & MRT & 0.001 & 0.000 & 0.000 & 0.001 \\
\hline & & & MRT to LMR & 0.455 & 0.030 & 0.398 & 0.513 & LMR & 0.002 & 0.001 & 0.001 & 0.004 \\
\hline & & & LMR to RRE & 1.000 & 0.011 & 0.000 & 1.000 & RRE & 0.297 & 0.020 & 0.260 & 0.338 \\
\hline & & & $\mathrm{RRE}$ to $\mathrm{MCN}$ & 0.707 & 0.094 & 0.499 & 0.854 & $\mathrm{MCN}$ & 0.145 & 0.019 & 0.111 & 0.185 \\
\hline & & & $\mathrm{MCN}$ to JDA & 1.000 & 0.000 & 1.000 & 1.000 & JDA & 0.054 & 0.001 & 0.041 & 0.073 \\
\hline & & & JDA to BON & 0.765 & 0.366 & 0.057 & 0.994 & $\mathrm{BON}$ & 0.118 & 0.055 & 0.045 & 0.275 \\
\hline & & & REL to TWL & 0.909 & 0.011 & 0.886 & 0.928 & ALL & 0.048 & 0.002 & 0.044 & 0.053 \\
\hline \multirow[t]{7}{*}{ METH } & \multirow[t]{7}{*}{$\mathrm{CHN}$} & \multirow[t]{7}{*}{5,972} & REL to MRT & 1.000 & 0.000 & 1.000 & 1.000 & MRT & 0.001 & 0.000 & 0.000 & 0.002 \\
\hline & & & MRT to LMR & 1.000 & 0.075 & 0.000 & 1.000 & LMR & 0.001 & 0.000 & 0.001 & 0.002 \\
\hline & & & LMR to RRE & 0.645 & 0.058 & 0.527 & 0.914 & RRE & 0.322 & 0.017 & 0.289 & 0.356 \\
\hline & & & $\mathrm{RRE}$ to $\mathrm{MCN}$ & 0.775 & 0.100 & 0.528 & 0.914 & $\mathrm{MCN}$ & 0.108 & 0.014 & 0.083 & 0.139 \\
\hline & & & $\mathrm{MCN}$ to JDA & 0.949 & 0.228 & 0.002 & 1.000 & JDA & 0.056 & 0.012 & 0.036 & 0.085 \\
\hline & & & JDA to BON & 0.925 & 0.430 & 0 & 1.000 & $\mathrm{BON}$ & 0.116 & 0.049 & 0.049 & 0.250 \\
\hline & & & REL to TWL & 0.945 & 0.009 & 0.926 & 0.960 & ALL & 0.062 & 0.002 & 0.057 & 0.067 \\
\hline \multirow[t]{4}{*}{ WINT } & \multirow[t]{4}{*}{$\mathrm{CHN}$} & \multirow[t]{4}{*}{10,872} & REL to MRT & 1.000 & 0.000 & 1.000 & 1.000 & MRT & 0.000 & 0.000 & 0.000 & 0.002 \\
\hline & & & MRT to LMR & 0.679 & 0.022 & 0.634 & 0.717 & LMR & 0.001 & 0.000 & 0.000 & 0.002 \\
\hline & & & LMR to RRE & 0.999 & 0.003 & 0.000 & 1.000 & RRE & 0.332 & 0.012 & 0.310 & 0.355 \\
\hline & & & $\mathrm{RRE}$ to $\mathrm{MCN}$ & 0.812 & 0.068 & 0.644 & 0.911 & $\mathrm{MCN}$ & 0.125 & 0.011 & 0.106 & 0.147 \\
\hline
\end{tabular}




\begin{tabular}{|c|c|c|c|c|c|c|c|c|c|c|c|c|}
\hline \multirow{8}{*}{ WINTBC } & \multirow{7}{*}{$\mathrm{CHN}$} & \multirow{7}{*}{5,973} & $\mathrm{MCN}$ to JDA & 0.877 & 0.123 & 0.431 & 0.985 & JDA & 0.072 & 0.009 & 0.056 & 0.093 \\
\hline & & & JDA to BON & 0.999 & 0.001 & 0.000 & 1.000 & $\mathrm{BON}$ & 0.102 & 0.013 & 0.079 & 0.129 \\
\hline & & & REL to TWL & 0.950 & 0.006 & 0.937 & 0.961 & ALL & 0.068 & 0.002 & 0.064 & 0.072 \\
\hline & & & REL to MRT & 1.000 & 0.000 & 1.000 & 1.000 & MRT & 0.001 & 0.000 & 0.000 & 0.002 \\
\hline & & & MRT to LMR & 1.000 & 0.000 & 1.000 & 1.000 & LMR & 0.001 & 0.000 & 0.000 & 0.002 \\
\hline & & & LMR to RRE & 0.707 & 0.029 & 0.647 & 0.760 & RRE & 0.319 & 0.015 & 0.291 & 0.348 \\
\hline & & & $\mathrm{RRE}$ to $\mathrm{MCN}$ & 0.872 & 0.090 & 0.583 & 0.971 & $\mathrm{MCN}$ & 0.139 & 0.014 & 0.113 & 0.170 \\
\hline & \multirow{7}{*}{$\mathrm{CHN}$} & \multirow{7}{*}{4,998} & $\mathrm{MCN}$ to JDA & 0.989 & 0.193 & 0.000 & 1.000 & JDA & 0.064 & 0.012 & 0.045 & 0.091 \\
\hline \multirow{6}{*}{ Twisp } & & & JDA to $\mathrm{BON}$ & 1.000 & 0.002 & 0.000 & 1.000 & $\mathrm{BON}$ & 0.083 & 0.015 & 0.058 & 0.118 \\
\hline & & & REL to TWL & 0.958 & 0.008 & 0.940 & 0.970 & ALL & 0.070 & 0.002 & 0.065 & 0.075 \\
\hline & & & REL to TWR & 0.958 & 0.021 & 0.890 & 0.985 & TWR & 0.507 & 0.013 & 0.482 & 0.534 \\
\hline & & & TWR to LMR & 0.654 & 0.039 & 0.574 & 0.726 & LMR & 0.001 & 0.000 & 0.000 & 0.003 \\
\hline & & & LMR to RRE & 1.000 & 0.000 & 1.000 & 1.000 & RRE & 0.407 & 0.020 & 0.368 & 0.446 \\
\hline & & & $\mathrm{RRE}$ to $\mathrm{MCN}$ & 0.607 & 0.083 & 0.438 & 0.753 & $\mathrm{MCN}$ & 0.084 & 0.013 & 0.001 & 0.007 \\
\hline \multirow{7}{*}{ COMBO } & \multirow{7}{*}{$\mathrm{CHN}$} & \multirow{7}{*}{38,669} & $\mathrm{MCN}$ to JDA & 0.928 & 0.174 & 0.075 & 1.000 & JDA & 0.130 & 0.019 & 0.096 & 0.172 \\
\hline & & & JDA to BON & 0.734 & 0.741 & 0.002 & 0.997 & $\mathrm{BON}$ & 0.023 & 0.023 & 0.003 & 0.147 \\
\hline & & & REL to TWL & 0.699 & 0.005 & 0.690 & 0.709 & ALL & 0.371 & 0.007 & 0.358 & 0.385 \\
\hline & & & REL to LMR & 0.638 & 0.014 & 0.611 & 0.664 & LMR & 0.001 & 0.000 & 0.001 & 0.002 \\
\hline & & & LMR to RRE & 1.000 & 0.011 & 0.000 & 1.000 & RRE & 0.329 & 0.007 & 0.316 & 0.342 \\
\hline & & & $\mathrm{RRE}$ to $\mathrm{MCN}$ & 0.817 & 0.040 & 0.725 & 0.883 & $\mathrm{MCN}$ & 0.124 & 0.006 & 0.112 & 0.136 \\
\hline & & & $\mathrm{MCN}$ to JDA & 0.924 & 0.082 & 0.555 & 0.992 & JDA & 0.068 & 0.005 & 0.058 & 0.079 \\
\hline \multirow{5}{*}{$\begin{array}{l}\text { COMBO - } \\
\text { No LMR }\end{array}$} & \multirow{5}{*}{$\mathrm{CHN}$} & \multirow{5}{*}{38,669} & JDA to BON & 1.000 & 0.010 & 0.000 & 1.000 & BON & 0.078 & 0.006 & 0.066 & 0.091 \\
\hline & & & REL to TWL & 0.802 & 0.003 & 0.795 & 0.809 & ALL & 0.118 & 0.002 & 0.115 & 0.131 \\
\hline & & & REL to RRE & 0.638 & 0.012 & 0.615 & 0.661 & RRE & 0.329 & 0.007 & 0.316 & 0.342 \\
\hline & & & $\mathrm{RRE}$ to $\mathrm{MCN}$ & 0.816 & 0.040 & 0.725 & 0.882 & $\mathrm{MCN}$ & 0.124 & 0.006 & 0.112 & 0.136 \\
\hline & & & $\mathrm{MCN}$ to JDA & 0.923 & 0.082 & 0.556 & 0.992 & JDA & 0.068 & 0.005 & 0.058 & 0.079 \\
\hline \multirow{6}{*}{ METH } & \multirow{6}{*}{ STH } & \multirow{6}{*}{5,305} & JDA to BON & 1.000 & 0.023 & 0.000 & 1.000 & $\mathrm{BON}$ & 0.078 & 0.006 & 0.067 & 0.091 \\
\hline & & & REL to TWL & 0.565 & 0.003 & 0.559 & 0.571 & ALL & 0.288 & 0.003 & 0.282 & 0.295 \\
\hline & & & REL to MRT & 0.947 & 0.092 & 0.334 & 0.998 & MRT & 0.000 & 0.000 & 0.000 & 0.001 \\
\hline & & & MRT to LMR & 1.000 & 0.000 & 0.000 & 1.000 & LMR & 0.000 & 0.000 & 0.000 & 0.001 \\
\hline & & & LMR to RRE & 0.998 & 0.088 & 0.000 & 1.000 & RRE & 0.383 & 0.017 & 0.349 & 0.417 \\
\hline & & & $\mathrm{RRE}$ to $\mathrm{MCN}$ & 0.539 & 0.053 & 0.435 & 0.640 & $\mathrm{MCN}$ & 0.065 & 0.007 & 0.052 & 0.081 \\
\hline
\end{tabular}




\begin{tabular}{|c|c|c|c|c|c|c|c|c|c|c|c|c|}
\hline & & & $\mathrm{MCN}$ to JDA & 1.000 & 0.000 & 1.000 & 1.000 & JDA & 0.093 & 0.010 & 0.076 & 0.115 \\
\hline & & & JDA to $\mathrm{BON}$ & 1.000 & 0.000 & 1.000 & 1.000 & $\mathrm{BON}$ & 0.125 & 0.013 & 0.103 & 0.153 \\
\hline & & & REL to TWL & 0.988 & 0.007 & 0.962 & 0.996 & ALL & 0.079 & 0.003 & 0.074 & 0.084 \\
\hline \multirow[t]{7}{*}{ WINT } & STH & 29,009 & REL to MRT & 1.000 & 0.000 & 1.000 & 1.000 & MRT & 0.000 & 0.000 & 0.000 & 0.001 \\
\hline & & & MRT to LMR & 1.000 & 0.009 & 0.000 & 1.000 & LMR & 0.001 & 0.000 & 0.001 & 0.001 \\
\hline & & & LMR to RRE & 0.644 & 0.015 & 0.615 & 0.673 & RRE & 0.410 & 0.009 & 0.035 & 0.047 \\
\hline & & & RRE to MCN & 0.668 & 0.044 & 0.577 & 0.748 & $\mathrm{MCN}$ & 0.040 & 0.009 & 0.392 & 0.428 \\
\hline & & & $\mathrm{MCN}$ to JDA & 1.000 & 0.000 & 1.000 & 1.000 & JDA & 0.057 & 0.004 & 0.041 & 0.065 \\
\hline & & & JDA to $\mathrm{BON}$ & 0.935 & 0.129 & 0.182 & 0.999 & $\mathrm{BON}$ & 0.124 & 0.016 & 0.097 & 0.158 \\
\hline & & & REL to TWL & 0.951 & 0.004 & 0.943 & 0.958 & ALL & 0.065 & 0.011 & 0.062 & 0.067 \\
\hline \multirow[t]{7}{*}{ TWISP } & STH & 5,429 & REL to TWR & 0.851 & 0.022 & 0.801 & 0.889 & TWR & 0.382 & 0.012 & 0.368 & 0.446 \\
\hline & & & TWR to LMR & 0.876 & 0.339 & 0.015 & 1.000 & LMR & 0.002 & 0.001 & 0.001 & 0.007 \\
\hline & & & LMR to RRE & 0.766 & 0.298 & 0.112 & 0.988 & RRE & 0.407 & 0.020 & 0.368 & 0.446 \\
\hline & & & $\mathrm{RRE}$ to $\mathrm{MCN}$ & 0.607 & 0.083 & 0.438 & 0.753 & $\mathrm{MCN}$ & 0.084 & 0.013 & 0.062 & 0.112 \\
\hline & & & $\mathrm{MCN}$ to JDA & 0.928 & 0.174 & 0.075 & 1.000 & JDA & 0.130 & 0.019 & 0.096 & 0.172 \\
\hline & & & JDA to BON & 0.856 & 0.258 & 0.090 & 0.997 & $\mathrm{BON}$ & 0.164 & 0.045 & 0.093 & 0.273 \\
\hline & & & REL to TWL & 0.746 & 0.005 & 0.736 & 0.756 & ALL & 0.263 & 0.006 & 0.253 & 0.274 \\
\hline \multirow[t]{6}{*}{ COMBO } & STH & 39,743 & REL to LMR & 0.997 & 0.060 & 0.000 & 1.000 & LMR & 0.001 & 0.000 & 0.001 & 0.001 \\
\hline & & & LMR to RRE & 0.677 & 0.043 & 0.588 & 0.754 & RRE & 0.404 & 0.008 & 0.390 & 0.419 \\
\hline & & & RRE to MCN & 0.617 & 0.030 & 0.556 & 0.674 & $\mathrm{MCN}$ & 0.051 & 0.003 & 0.045 & 0.057 \\
\hline & & & $\mathrm{MCN}$ to JDA & 0.999 & 0.002 & 0.000 & 1.000 & JDA & 0.072 & 0.004 & 0.065 & 0.080 \\
\hline & & & JDA to $\mathrm{BON}$ & 0.962 & 0.107 & 0.073 & 1.000 & $\mathrm{BON}$ & 0.128 & 0.013 & 0.104 & 0.156 \\
\hline & & & REL to TWL & 0.815 & 0.003 & 0.818 & 0.821 & ALL & 0.125 & 0.002 & 0.121 & 0.128 \\
\hline \multirow{5}{*}{$\begin{array}{l}\text { COMBO - } \\
\text { No LMR }\end{array}$} & STH & 39,743 & REL to RRE & 0.674 & 0.012 & 0.651 & 0.697 & RRE & 0.404 & 0.008 & 0.390 & 0.419 \\
\hline & & & $\mathrm{RRE}$ to $\mathrm{MCN}$ & 0.617 & 0.030 & 0.556 & 0.674 & $\mathrm{MCN}$ & 0.050 & 0.003 & 0.045 & 0.056 \\
\hline & & & $\mathrm{MCN}$ to JDA & 0.999 & 0.002 & 0.000 & 1.000 & JDA & 0.071 & 0.003 & 0.065 & 0.080 \\
\hline & & & JDA to $\mathrm{BON}$ & 0.963 & 0.106 & 0.076 & 0.998 & $\mathrm{BON}$ & 0.128 & 0.013 & 0.104 & 0.156 \\
\hline & & & REL to TWL & 0.575 & 0.003 & 0.569 & 0.581 & ALL & 0.308 & 0.003 & 0.302 & 0.315 \\
\hline
\end{tabular}


Publishing support provided by the U.S. Geological Survey

Publishing Network, Tacoma Publishing Service Center

For more information concerning the research in this report, contact the

Director, Western Fisheries Research Center

U.S. Geological Survey

6505 NE 65th Street

Seattle, Washington 98115

http://wfrc.usgs.gov/ 
